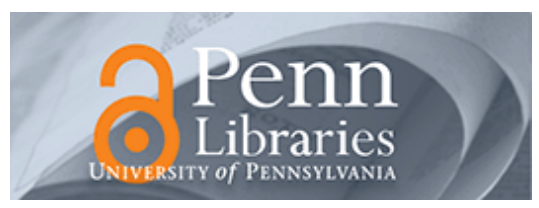

Studies in Visual Communication

Volume 7

Issue 1 Winter 1981

Article 2

1981

\title{
A Sociovidistic Approach to Children's Filmmaking: The Philadelphia Project
}

Richard Chalfen

\section{Recommended Citation}

Chalfen, R. (1981). A Sociovidistic Approach to Children's Filmmaking: The Philadelphia Project. 7(1), 2-32. Retrieved from https://repository.upenn.edu/svc/vol7/iss1/2

This paper is posted at ScholarlyCommons. https://repository.upenn.edu/svc/vol7/iss1/2

For more information, please contact repository@pobox.upenn.edu. 
A Sociovidistic Approach to Children's Filmmaking: The Philadelphia Project 


\title{
A Sociovidistic Approach to Children's Filmmaking: The Philadelphia Project
}

\author{
Richard Chalfen
}

\section{Introduction}

During the summer of 1966 I had the good fortune to work as a research assistant to Sol Worth and John Adair on their National Science Foundation project entitled "The Use of Film in Cross-Cultural Communications." During that time I had the rare opportunity of introducing filmmaking technology to selected members of non-Western society-the Navajo-and, subsequently, to observe the production of six Navajo-made documentary films. Impressed by the unexplored research potential of this approach, I began to organize a sequence of film communication projects in Philadelphia. Between 1967 and 1979 I worked with eight groups of lower- and middle-class teenagers, a women's liberation group, a politically active lesbian group, a sample of middle-class home moviemakers, and most recently, a sample of Polavision users.

In 1970 Sol and John asked me to write a report of comparative research findings for inclusion in their book on the Navajo Project. That paper, originally entitled "Socio-Documentary Filmmaking in an Urban Setting,' appeared as Chapter 15 in Through Navajo Eyes-An Exploration in Film Communication and Anthropology (1972). The purpose of that chapter was, first, to provide comparative data on utilizing a particular research method grounded in ethnographic and participant observation techniques; and, second, to compare examples of film communication across several groups of teenagers from different sociocultural backgrounds. The need arose to explain how Worth's "bio-documentary" techniques-originally developed from work with graduate students enrolled in a documentary film workshop (Worth 1963, 1965) and later used in the Navajo Project-could be applied to groups of teenage novice filmmakers. In addition further evidence was sought regarding the speculation that the first use of $16 \mathrm{~mm}$ filmmaking technology neutralized different social and cultural variables in the production of filmic symbolic forms.

The following article is intended as a clarification, expansion, and updating of several points made in Through Navajo Eyes.

Richard Chalfen is Director of the Masters Program in Visual Anthropology at Temple University. His recent work includes studies of home mode visual communication, tourist photography, and media anthropology.

\section{Literature on Children's Filmmaking}

In 1972 we reported an enormous growth in the frequency and variety of teenage filmmaking projects across the country. Settings for these projects include elementary schools, high schools, storefront centers, settlement houses, church clubs, various workshops, mental health clinics, art centers, detention homes, and jails, among others. Given this diversity in settings, we also find considerable variety in teaching techniques, in relationships between adults as instructors and young people as students and in the motivations, objectives, expectations, and rewards of different personnel.

In a recent review of the literature on children's filmmaking, Aristarco (1980) outlines three predominant categories of activity. A variety of reports have been published on filmmaking projects in primary and secondary schools (e.g., Brasso 1974; Carrico 1969; Culkin 1966; Hilton 1973; Hodgkinson 1964; Kohl 1975; Reinecke 1974). Another collection of publications reports on movies made by workshops and film clubs in different communities and neighborhoods (e.g., Anderson 1969; Bigby 1968; Larson 1966, 1969; Lidstone and Mclntosh 1970; Peavy 1969; Robbin 1966). A third category of writing describes films produced as part of structured research projects (e.g., Achtenberg 1967; Chalfen 1974; Chalfen and Haley 1971; Norlin 1966; Sutton-Smith 1977, 1979; Evans et al. 1979).

Two characteristics of this literature limit the possibilities of its use in communications research. There appears to be a reluctance for or disinterest in writing detailed reports of individual projects-successful ones as well as unsuccessful ones-that include descriptive information on social and cultural context. Second, few observers attempt to concentrate on similarities and/or differences in filmmaking experiences and films produced by similar or different groups of teenagers. Generalizations regarding all teenagers are more common than comparative statements. In short, interesting research questions regarding the production of symbolic forms in differing sociocultural contexts have been generally ignored. Interest in the successful production of teenage movies has eclipsed any sustained inquiry into how film works as a mode of film communication for young people.

With these general limitations in mind, I want to include several unusual comments that relate to the research described in this article. Several reports contain insightful hints of social and cultural variation in the production and interpretation of teenage-made films. In one, John Bigby described the results of a third-grade teacher who had her students use cameras in Harlem in 1965:

The thing I can't forget about those movies, made by eightyear-old black children, is their awful vision. ... I remember crossed steel everywhere. The folding gates across store windows, the metal fences around the schoolyards ... the physical barriers everywhere. ... Those Harlem filmmakers showed me, in flickering images on the wall of a real slum 
school with real rats, why I was afraid. ... I keep wondering what over-privileged kids could see with an $8 \mathrm{~mm}$ camera. [1968:20-21]

David Mallery in his chapter on "The Young Film Makers Explosion" says that some people seeing films made by young people were:

impressed by how technically polished they were. Others spoke of the creativity, imagination, and reflection of young people's background, personalities and concerns shown in the films and in the conversations [about the films]. Still others worried over a kind of "we"-and-"they" division between middle-class students with their film and the slum students with theirs. [1968:23]

\section{Mallery goes on to say parenthetically:}

There continues to be a lot of talk and study about some of the noticeable differences in the action, subjectmatter, and the styles of the films made by young people in the ghettos and those made in the "advantaged" schools and areas. [ibid.]

However, in spite of the fact that Mallery mentions this "interest and study," he gives no reference to any such work in what is otherwise a well documented and referenced publication.

In two separate newspaper reports of Rodger Larson's work with the "Movie Bus" on the Lower East Side of New York, a correlation is suggested between the class or the socioeconomic status of the filmmakers and the films they produce. Larson is quoted as saying:

The films that come out of poor areas are often about fights.... In the middle class, they're very narcissistic: at fifteen or sixteen if a girl makes a film the camera lingers lovingly on a girl; if a boy is behind the camera the camera lingers lovingly on a boy. And the upper class, those films aren't about people; they're abstract, the people are symbols. [Roddick 1967:2]

But again there was no comparative follow-up to these observations. And in another write-up of the University Settlement House work with Larson:

The teenagers at Montefiore are mostly middle class on the economic scale, some decidedly upperclass, and the concerns and interests differ markedly, naturally enough, from those of the University Settlement group. Here again the film titles- "Only a Dream", "Yesterdays"; "Arabesque" are indicative of the content, in these cases more introspective and hooked on "poetic" images than their counterparts downtown. [O'Connor 1967]
In another brief article about films made in primary and secondary schools, Paul Carrico remarks that in "innercity schools they [student-made films] tend to be about people interacting with other people. Affluent students make more abstract films replete with alienation and protest"' (1969:16).

Infrequent observations of this kind beg many important questions relevant to a sociocultural approach to communication research. The need arises to examine carefully how film communication is organized and works for different groups of people. If adolescents are making different kinds of film that are provoking positive and negative reactions, can any generalizations be made to account for the likes and dislikes, the similarities and dissimilarities? Are different patterns of film communication involved? What are the different groups relating to, and reacting to, when asked to see and evaluate a film? Are non-overlapping social contexts involving class, race, and sex structuring the production and interpretation of the film communication? Exploration of these questions is facilitated by using a structured plan of observation described in the following pages.

\section{A Sociovidistic Perspective}

Several instructive differences exist between the way Worth and Adair chose to discuss the Navajo materials and the methods of description and analysis operationalized for the Philadelphia research. Both projects utilized a codes-in-context approach to visual communication (Worth and Adair 1972:139, 233). While Worth emphasized the level of film code (especially observed encoding habits and conventions), I explored the use of a structured approach to code context. This difference is better understood by clarifying and comparing notions of "vidistics" and "sociovidistics."

In 1966, while reviewing the problematic conceptualization and status of film as "language," Worth proposed the notion of vidistics:

Vidistics in this early state is concerned, first, with the determination and description of those visual elements relevant to the process of communication. Second, it is concerned with the determination of the rules, laws and logic of visual relationship that help a viewer to infer meaning from an Image-Event, and the interaction of Image-Events in sequence. Film as if it were language, as studied vidistically, is thus thought of as the study of specified elements, elements in sequence, operations on those elements, and cognitive representations of them that act as a mediating agent in a communications process between human beings-between a filmmaker and a viewer - between a creator and a re-creator. [1966:331] 
It is apparent that Worth used a vidistic formulation when he organized the Navajo Project and when he analyzed the results: "We have decided to build our analysis around a presentation of differences between our films and the Navajo films on the level of code" (1972:141; emphasis added). Worth concentrated on several vidistic elements: (1) narrative style, (2) syntactic organization and "sequencing of events and units of eventing, " (3) cultural, perceptual, and cognitive restrictions influencing organization and structure, and (4) relationships between film structure and verbal language structure (1972:140). Thus a continuity was maintained that emphasized encoding and decoding as cognitive activity, rule-like sequence of visual units, and speculative relationships between culturally structured communicative codes.

Whereas Worth found cognitive and syntactic features of the code most fruitful for comparative analysis, research described in this report stresses the social dimensions of the vidistic formulation, hence the term "sociovidistics." "2 Sociovidistics is understood as the systematic description and analysis of visual (pictorial) symbolic forms as embedded in a process of social communication. Sociovidistics suggests that the production, use, and interpretation of pictorial forms be studied as a social process, operating in social contexts-a process that is determined by, and identified as, culturally structured behavior. Borrowing from Byers and Worth, sociovidistics studies the entire cultural enterprise of people constructing and producing pictorial forms, becoming symbolically represented in pictorial forms, and using, viewing, and interpreting pictorial forms. Furthermore, specific attention is given to the social and psychological functions related to code use and to the dynamics of implication and inference that operate between image-makers and image-viewers.

The thrust of reformulating certain vidistic principles was to clarify how specific contextual features constitute a useful mode of description and analysis of filmmaking activity-activity that constitutes film as a symbolic form of visual communication. ${ }^{3}$

Sociovidistic theory implicitly asserts that the patterning of pictorial forms of visual communication must go beyond discovering laws of "grammar" or conventions of syntactic structure to understand the relationship of pictorial imagery to social life. While sociovidistics has been suggested as a term for an area of research that integrates concerns in vidistics, visual communication, and cultural anthropology, the "ethnography of pictorial communication" designates a particular mode of inquiry devoted to explicating the patterned organization of pictorial and sociocultural domains. ${ }^{4}$
A sociovidistic scheme of description serves as a guide for doing ethnographies of pictorial (in this case, film) communication. By use of ongoing research in sociolinguistics, specifically the ethnography of speaking (Hymes 1964, 1972), parallels were developed between speech events and film communication events. In the latter it becomes necessary to study four kinds of events: (1) planning events, (2) filming events (which necessarily include the two subcategories of "on-camera" events and "behind-camera" events), (3) editing events, and (4) exhibition events. In turn, each of these communication events should be cross-referenced with a series of "components." Whereas Hymes has suggested as many as sixteen components relevant to speech events (1972:58-65), only five have proved useful for film communication: (1) participants, (2) topics, (3) settings, (4) message form, and (5) code. Cross-referencing these events and components produces a type of sociovidistic etic grid (Chalfen 1974:10-16). Formulation and use of this grid force a recognition and consideration of relationships between contextual features that otherwise remain unproblematic. The sociovidistic framework provides a means of producing systematic descriptions and comparisons of visual communication-across a variety of pictorial forms, across different photographic and filmic genres, and across production and use of images in different cultures. Specific examples of how this framework can be applied to children's "sociodocumentary" filmmaking is the subject of the following pages.

\section{The Philadelphia Project: Sociodocumentary Research Design}

The research was designed, in part, to be compatible with previous fieldwork by Worth and Adair (1972) and with similar efforts by Worth and his students (1964, 1965; Achtenberg 1967). The basic similarity of these projects is that research subjects were taught, observed, and interviewed as they produced $16 \mathrm{~mm}$ films about themselves for the first time. Care was taken to standardize procedures and specify research conditions to facilitate future studies for additional comparative findings. ${ }^{5}$

Subjects for the project were selected according to a pattern of social characteristics. Eight groups of five 14to 16-year-olds were invited "to make a movie." Although each group came from different neighborhoods, all subjects lived within the city limits of Philadelphia. Each group was a "natural" group-members were neighborhood friends who socialized together for various leisure activities. In addition, all the selected groups had easy access to one of the buildings of the Philadelphia Child Guidance Clinic. Since groups of people were making a film together, the term "sociodocumentary" has been used instead of "bio-documentary" (Worth and Adair 1972:231-232). 
Initially I attempted to contact a sample of subjectgroups that conformed to a $2 \times 2 \times 2$ experimental paradigm. Using independent variables of social class, ethnicity, and sex, I wanted to compare the filmmaking behavior of middle-class vs. lower-class teenagers, ${ }^{6}$ blacks vs. whites, and males vs. females. However, not all the required groups could be contacted.

\section{Introductory Procedures}

All subjects were introduced to sociodocumentary filmmaking in the same manner. Identical instructions, methods, and equipment were used with each participating group. The standardized schedule of activities and operating procedures consisted of four sections: (1) introductory/practice sessions, (2) film planning sessions, (3) film production sessions, which included filming and editing, and (4) film exhibition sessions.

The first section consisted of seven meetings which were more standardized than the others. According to a verbal contract-agreement each group was invited to learn $16 \mathrm{~mm}$ filmmaking and produce a movie on any topic of their choosing in exchange for letting us (in this case, Jay Haley ${ }^{7}$ and myself) do research on their filmmaking behavior. As a group they had to choose (1) what the film was about, (2) where to shoot (any location was permissible within a 15-minute driving radius of our regular meeting place), (3) who (if anyone) and/or what (if anything) was to be in the film, (4) the production personnel, (5) the length, and (6) an appropriate sound track. Each subject was required to have a parent sign a legally drawn release form for their participation either in a movie or in the making of a movie.

The first seven sessions were devoted to introducing the general idea of the project, to demonstrating the filmmaking equipment, having subjects practice their filming in both indoor and outdoor conditions, viewing practice rushes, and discussing ideas for their film. At the conclusion of the seventh session the group was informed that they could start their cooperative production whenever they felt ready. Subjects were reminded that their film was to be a cooperative effort; group agreements were important. They understood that I could help only with technical matters. A time limit of 6 months was stressed.

According to the research design, the second and third sections of the project began after the seventh session. The group worked at conceiving, developing, or changing their film ideas, shooting film, viewing rushes, editing, and recording a sound track.

When the group agreed that their film was complete, there was a recess in the regular meeting schedule while the film laboratories made $A$ and $B$ rolls, transferred the sound to an optical track, and made the first answer print. The filmmaking group was then reconvened for the fourth set of sessions which consisted of screening their finished film and viewing other project-made films.

\section{Observational Methods and Technical Specifications}

Data on events, activities, and behavior occurring as part of each filmmaking project was recorded by several methods. (1) A written journal of relevant observations was maintained for each project. (2) Tape recordings were made of nearly all 225 sessions and have subsequently been totally or selectively transcribed. (3) $35 \mathrm{~mm}$ black-and-white still photographs were regularly taken at different phases of each group's project. (4) A film log was organized to record each piece of film shot by each subject in each project; thus each shot was identified and cataloged by cameraman, description of content, length and type of shot, and so on. (5) In addition, $35 \mathrm{~mm}$ black-and-white still negatives and prints were made from representative $16 \mathrm{~mm}$ frames of each practice shot made by each filmmaking group. Contact sheets of these negatives were then inserted into the film log for further identification.

All the sociodocumentary filmmakers worked with the same pieces of professional $16 \mathrm{~mm}$ filmmaking equipment. All subjects used Bell and Howell Filmo $70 \mathrm{DH}$ and DR triple lens turret cameras equipped with Angenieux lenses of $75 \mathrm{~mm}, 25 \mathrm{~mm}$, and $10 \mathrm{~mm}$ focal length; Norwood Seconic light meters and a Quick Set tripod. A 50foot tape measure was available for correct focus settings. All the filmmakers used the same equipment to edit their $16 \mathrm{~mm}$ workprints, specifically, Griswold splicers, Zeiss Moviscop viewers, and Moviola rewinds. Sound recordings were made on $1 / 4$-inch magnetic tape with a Sony 800 recorder. The black-and-white film stock was a standard Kodak Plus X (ASA 125) and $4 X$ (ASA 500) negative film. Film processing was done in both New York and Philadelphia laboratories, thereby facilitating the return of rushes in less than a week. All filmmaking subjects also learned to use a Kodak Pageant projector to screen their rushes and edited workprints.

\section{The Emergence of Three Sociovidistic Patterns}

When the results of the eight sociodocumentary film projects were examined by use of the sociovidistic framework, three distinct patterns of behavior emerged. Two of these patterns will be described as "stable" and one as "unstable." Summaries of the films produced by each group are given in the Appendix.

Patterns of filmmaking behavior were labeled stable when subjects appeared to develop a consistent strategy for making a movie. The filmmakers, as a group, maintained a similar and consistent way of working throughout the moviemaking process. They reported consistent attitudes toward shooting, editing, and showing their films. These filmmakers seldom changed their choices of appropriate subject matter from their initial practice footage through the completion of the project. 


\section{Table 1}

Tabular Summary of Filmmaking Activity

\begin{tabular}{lcccccccc} 
& \multicolumn{2}{c}{ Stable Pattern I } & \multicolumn{2}{c}{ Stable Pattern II } & \multicolumn{3}{c}{ Unstable Pattern III } \\
\hline Group Number & 1 & 2 & 3 & 4 & 5 & 6 & 7 & 8 \\
\hline Total Sessions in Each Project & 21 & 23 & 9 & 49 & 54 & 8 & 53 & 8 \\
\hline Planning Sessions & 9 & 10 & 7 & 17 & 17 & 7 & 15 & 6 \\
\hline Filming Sessions & 5 & 6 & 2 & 13 & 16 & 1 & 19 & 2 \\
\hline Editing Sessions & 5 & 3 & - & 16 & 17 & - & 18 & - \\
\hline Exhibiting Sessions & 2 & 4 & - & 3 & 4 & - & 1 & - \\
\hline Practice Footage & $200^{\prime}$ & $200^{\prime}$ & $300^{\prime}$ & $400^{\prime}$ & $600^{\prime}$ & $200^{\prime}$ & $400^{\prime}$ & $400^{\prime}$ \\
\hline Total Footage & $600^{\prime}$ & $700^{\prime}$ & $300^{\prime}$ & $2100^{\prime}$ & $3100^{\prime}$ & $200^{\prime}$ & $3100^{\prime}$ & $400^{\prime}$ \\
\hline Length of Final Film & $478^{\prime}$ & $271^{\prime \prime}$ & - & $251^{\prime}$ & $493^{\prime}$ & - & $1407^{\prime}$ & - \\
(min./sec.) & $13^{\prime} 17^{\prime \prime}$ & $7^{\prime} 30^{\prime \prime}$ & - & $7^{\prime} 00^{\prime \prime}$ & $13^{\prime \prime} 42^{\prime \prime}$ & - & $39^{\prime} 05^{\prime \prime}$ & - \\
\hline Shooting Ratio & $1: 1.3$ & $1: 1.8$ & - & $1: 6.3$ & $1: 5.1$ & - & $1: 1.9$ & -
\end{tabular}

\section{Table 2}

Comparative Times [Number of Sessions] Devoted to Each Event by Each Film Group

\section{Stable}

Pattern I

Stable

Pattern II

Group 4

Group 5

Unstable

Pattern III

Group 6*

Group 7

Group 8*

\section{Number of sessions}
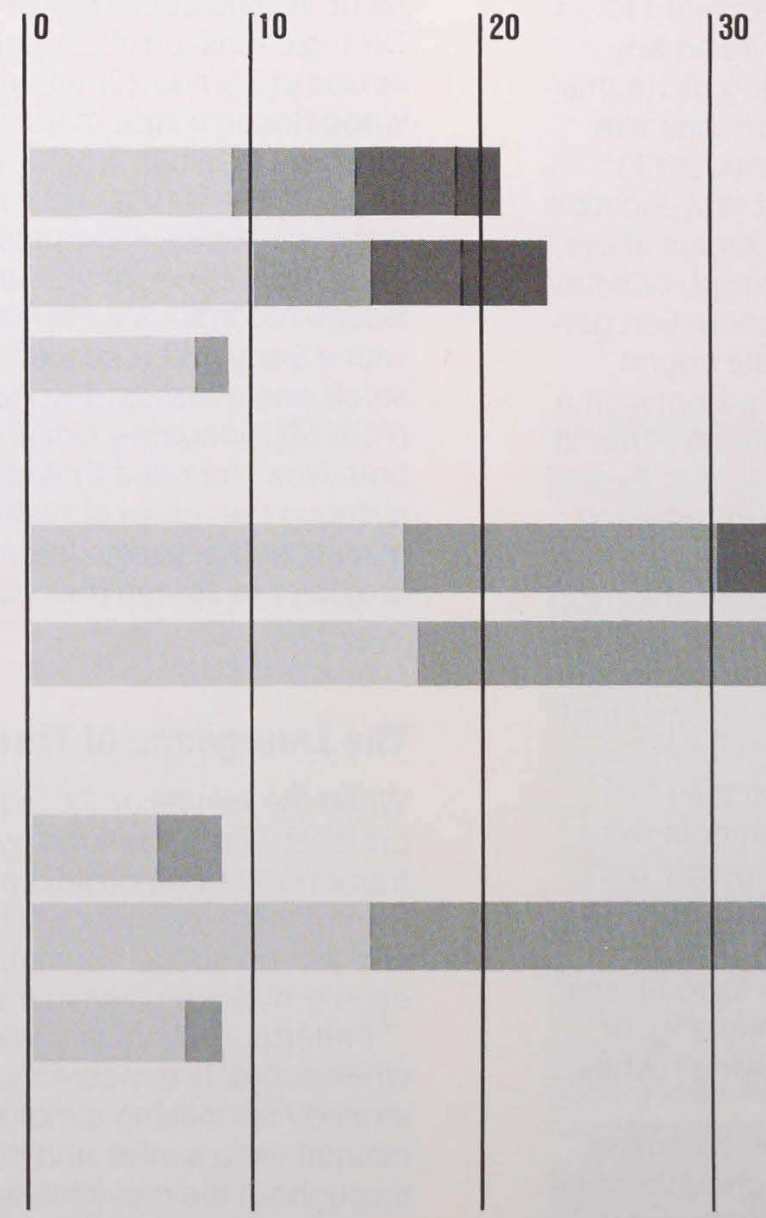

40

50

60

*Completed practice footage only 
In contrast, the unstable pattern is characterized by "shifting behavior." Behavioral shifts occurred in several ways: filmmaking subjects drastically changed their choices of appropriate subject matter or camera technique after they viewed their practice rushes. In another instance, the filmmakers might decide to start over after filming several hundred feet of film. Examples of other inconsistencies were observed more frequently in the filmmaking of the unstable groups than the stable ones.

Characteristics of Stable Pattern I (SP I) emerged from three projects comprised of black lower-class groupsone group consisted of all girls, two groups, all boys (groups 1, 2, and 3 in Tables 1 and 2). In marked contrast, characteristics defining Stable Pattern II (SP II) developed from observations and analysis of two white middle-class groups-one male, the other female (groups 4 and 5 in Tables 1 and 2). In contradistinction to these two stable yet contrasting patterns, an Unstable Pattern (USP III) of sociovidistic behavior emerged from three other groups in the project (groups 6, 7 and 8 in Tables 1 and 2). Subjects in this third pattern came from black middle-class and white lower-class backgrounds.

A summary of quantitative data associated with each sociovidistic pattern and each filmmaking group appears in Table 1. A schematic representation of comparative event activity is found in Table 2. Discussion of selected points in Tables 1 and 2 and descriptive summaries of SP I and SP II will be presented next. Characteristics of Unstable Pattern III will be described later.

\section{Stable Pattern I: Characteristics of Black Lower- Class Filmmaking}

(a) Stable Pattern I is characterized by devoting more time to planning than any other event. During the planning sessions, group members tended to ask more questions related to social aspects of the project than to technical (camera-related) ones. In addition, many topics other than filmmaking were discussed. Members of SP I groups found it difficult to mutually agree on any single film idea during their planning sessions. One idea was accepted by the group after one member wrote an outline or script for a film.

(b) Stable Pattern I filmmakers tried to finish planning their movies before they did any filming. Planning for SP I groups included a lot of preparation for shooting, such as deciding who would be allowed to act in specific roles, who could watch their filmmaking, what everybody should wear, how a room (or set) should be decorated, and similar questions.

(c) The second most time-consuming event, and the event of most interest to SP I filmmakers, was filming. Members of these groups spent more time filming than either editing or exhibiting. (d) The filming emphasis for these groups was on their on-camera rather than behind-camera activity. They competed for on-camera appearances, which usually took the form of acting in short sequences, scenes, or skits. Their acted performances were often rehearsed and often directed by the author of the script. For groups in SP I, making a movie meant being-in a movie. They tended to deemphasize behind-camera activity.

(e) In addition, the SPI groups shot much less film than other groups. They tried to photograph their subject matter only once and to shoot their film in the order prescribed by the scripted story line. Members of these groups tended not to experiment with the filmmaking equipment.

(f) Stable Pattern I groups did not like to edit their footage. They spent less time in editing than in planning or filming. One or two of the group members (in contrast to other patterns described below) did most of the cutting and splicing which was predetermined by the shooting plan and the story line.

(g) Exhibition events in Stable Pattern I received the least amount of attention.

In characterizing the components of Stable Pattern I, participants will be described first. These filmmakers were self-selected from larger social groupings (gangs and clubs), and the groups tended to enlarge beyond a five-member group as the project progressed. However, the general behavior of the participants changed in different events. For instance, all group members tried to participate equally when they were being filmed (in oncamera activity). However, individual group members had to perform tasks related to planning, behind-camera filming, and editing.

In addition, SP I members generally insisted on having certain contemporary "familiars" involved in their film and filmmaking; only their group members and selected friends, who temporarily joined their extended group, could be in their movie. Non-group-affiliated people and strangers were kept out of their footage. They also chose audiences of familiar people to see their films.

Stable Pattern I groups selected local and familiar settings for their films. They preferred to film in places where they were known (but not in their own homes) and in places where they frequently socialized. SP I filmmakers consistently selected familiar urban-residential environments as shooting locations.

These filmmakers consistently filmed topics, themes, and activities that involved showing themselves doing the familiar things that they liked to do on a day-to-day basis. A regularly recurring set of activities included acted skits of fighting, drinking, dancing, forms of competition, and sports activity. 
In terms of message form, SP I subjects preferred to work from a script (girls more than boys) and to record realistic and familiar versions of common events in their lives. Their films contained a story line which consisted of short episodes with distinguishable or logical beginnings and ends. These films take their forms from theater and their content from street life. SP I filmmakers preferred to make films as visual records that documented and glorified their lifestyles.

Code characteristics of the Stable Pattern I groups deemphasized the manipulation of cinematic units. Most of their original footage remained unedited in their finished films. Sequences of action contained few cuts, and there was a minimal amount of time and space manipulation or alteration. These filmmakers wanted sound and image to match and hence they attempted syncsound filming. Finally, these films were characterized by very low shooting ratios.

The following photographs have been taken from individual frames of $16 \mathrm{~mm}$ film shot during practice sessions.

\section{Illustrations 1-12}

Fighting, dancing, smoking, and drinking were chosen as highpriority activities for on-camera performance by SPI groups. In all of these examples, the teenagers chose to film themselves, resulting in a meta-message of "look-at-me." In contrast, neither of the white middle-class groups selected these kinds of on-camera topics.

12 Scenes of the filmmakers fighting with one another appeared in practice and final films made by all three SP I groups-male and female.

3 Related to fighting ability, demonstrations of strength-specifically muscle-flexing-were filmed by members of Group 2 (females) and Group 3 (males).

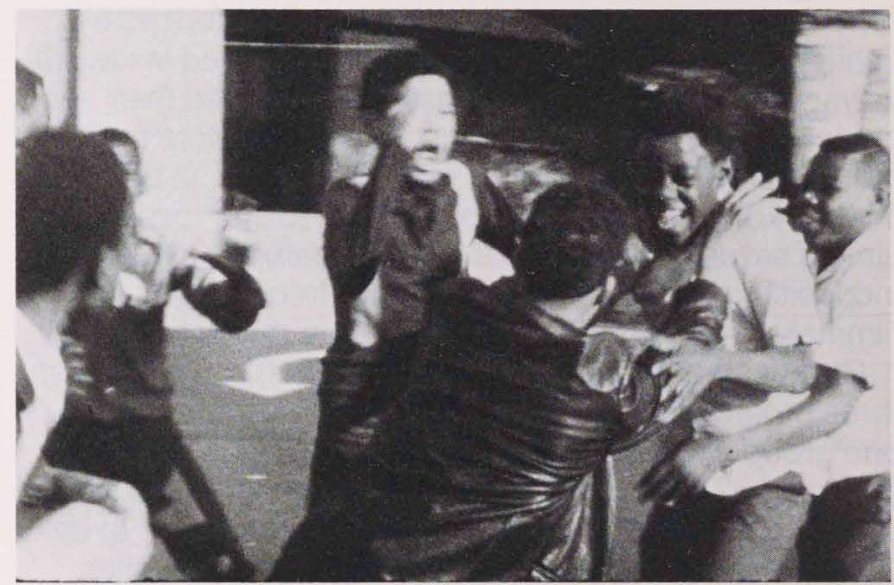

\section{Illustration 1}

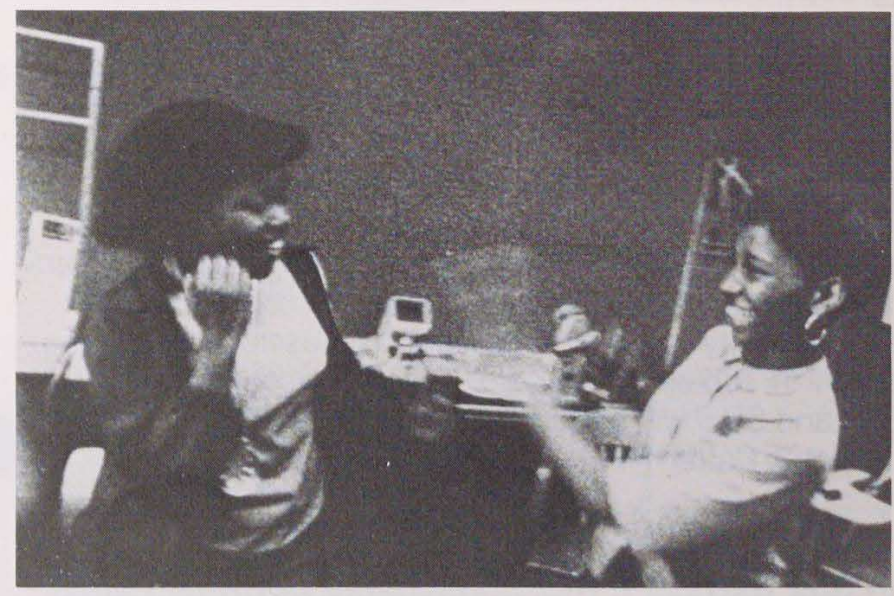

Illustration 2

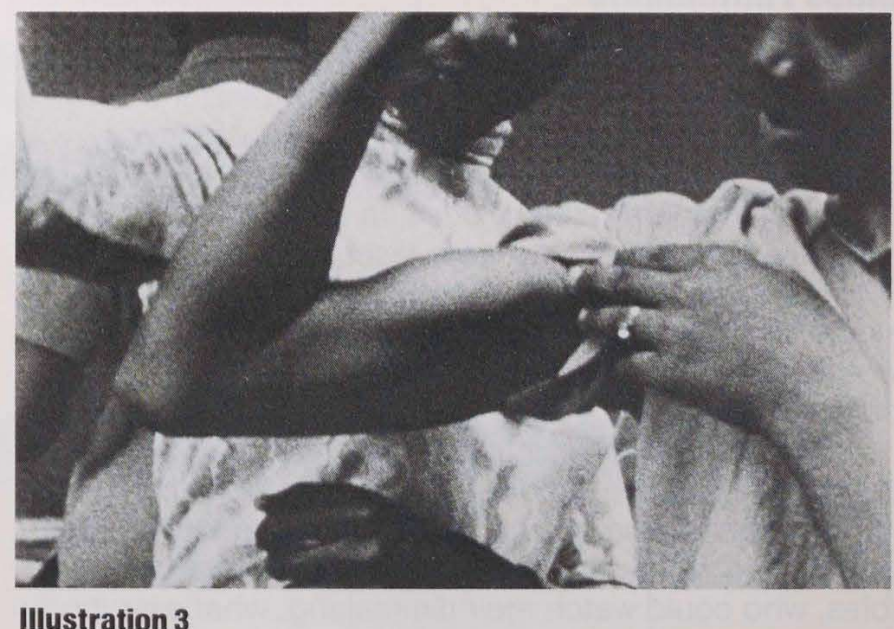




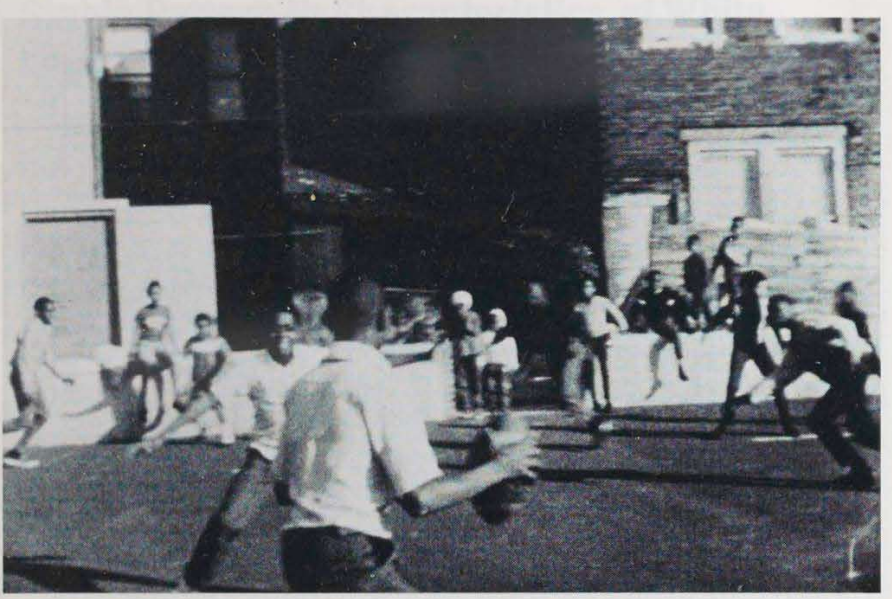

Illustration 4

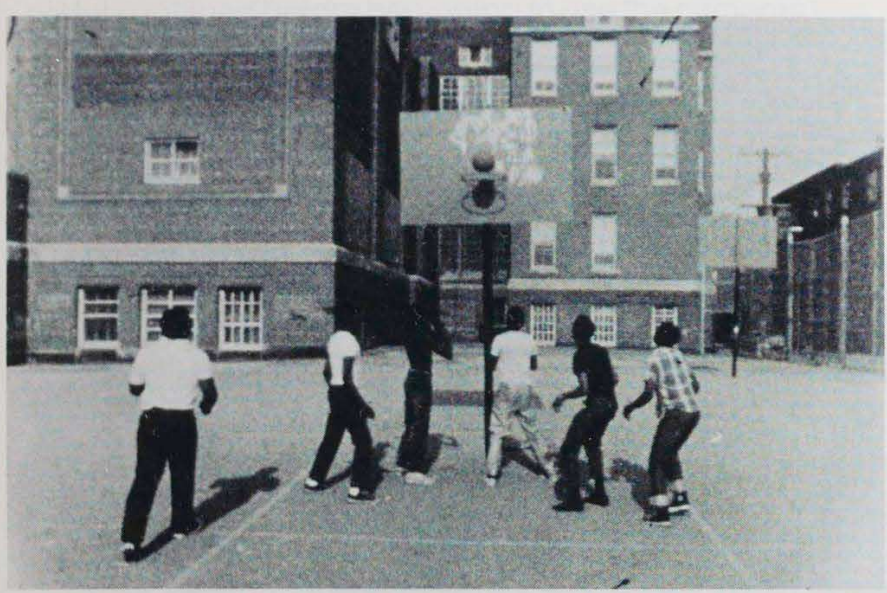

Illustration 5

45 The two male SP I groups (Groups 1 and 3) enthusiastically filmed long scenes of themselves in several types of sports activity. Scenes included football, basketball, track events, and Ping-Pong. Competition between group members both for athletic superiority and for the best on-camera performance were very common. In contrast, neither SP I| group filmed sports activity, though the female group shot scenes of a football game between teams from the police department and a local rock radio station.

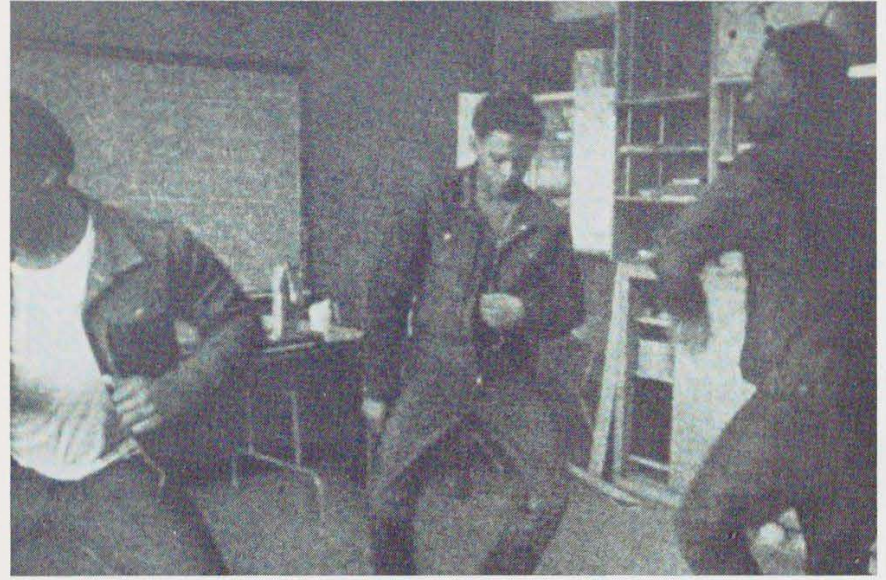

\section{Illustration 6}

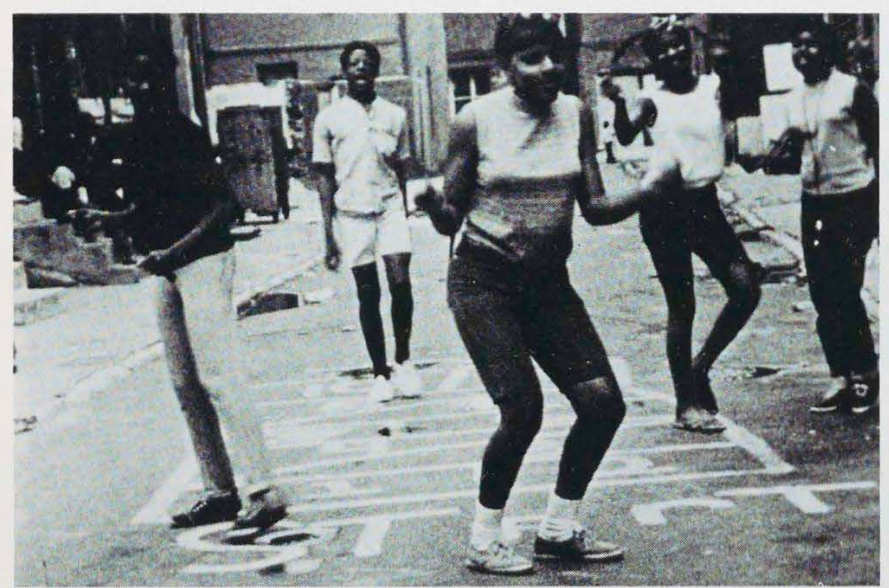

\section{Illustration 7}

67 Some form of dancing was filmed by all three SP I groups. Importance was given to "center stage" performance and the demonstration of dance style. 
89 Demonstration of smoking style was another form of favored on-camera activity. Smoking appeared as another informal kind of competition between group members.

10 Drinking and acting drunk played central roles in both final films produced by SP I groups. Scenes of group drinking were closely tied to partying and fighting. In contrast, these activities were absent from SP II-made films.

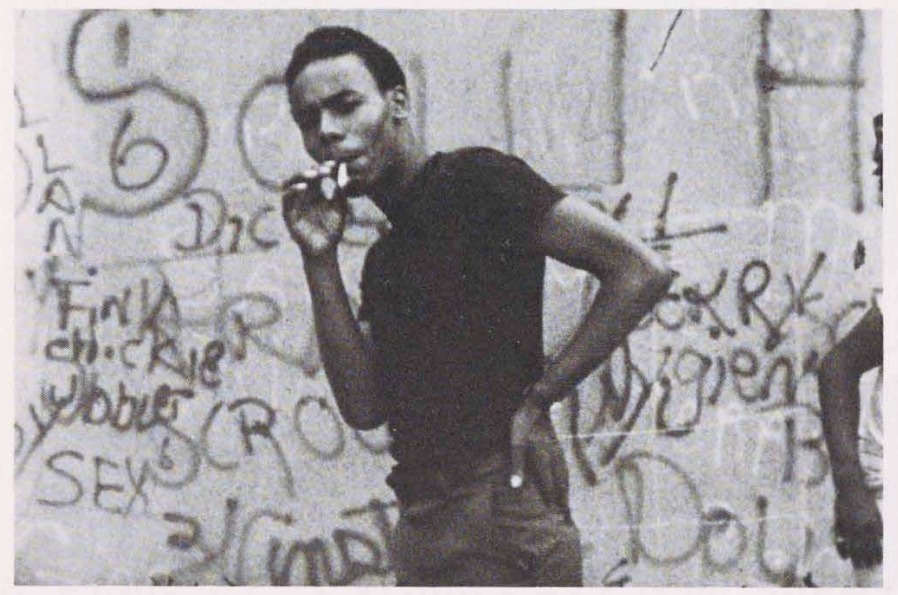

Illustration 8

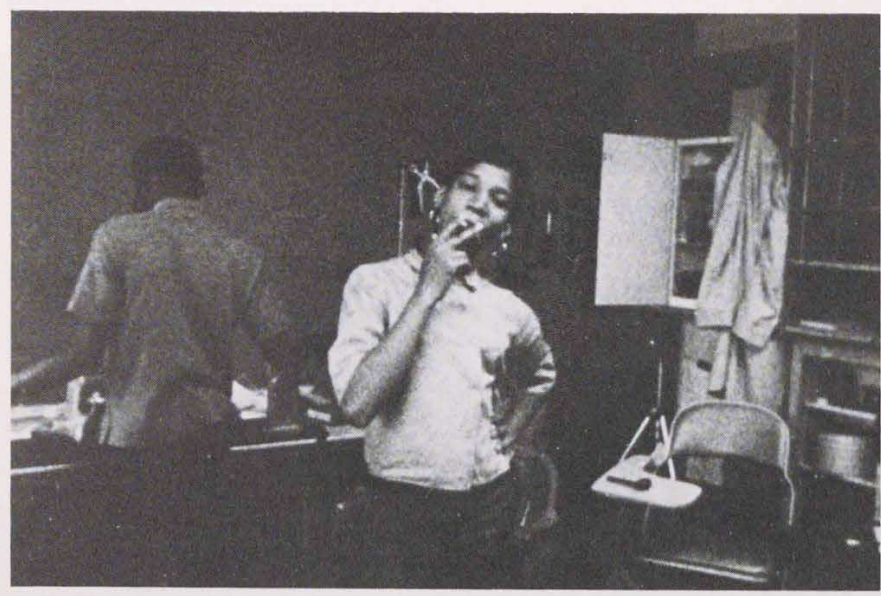

Illustration 9

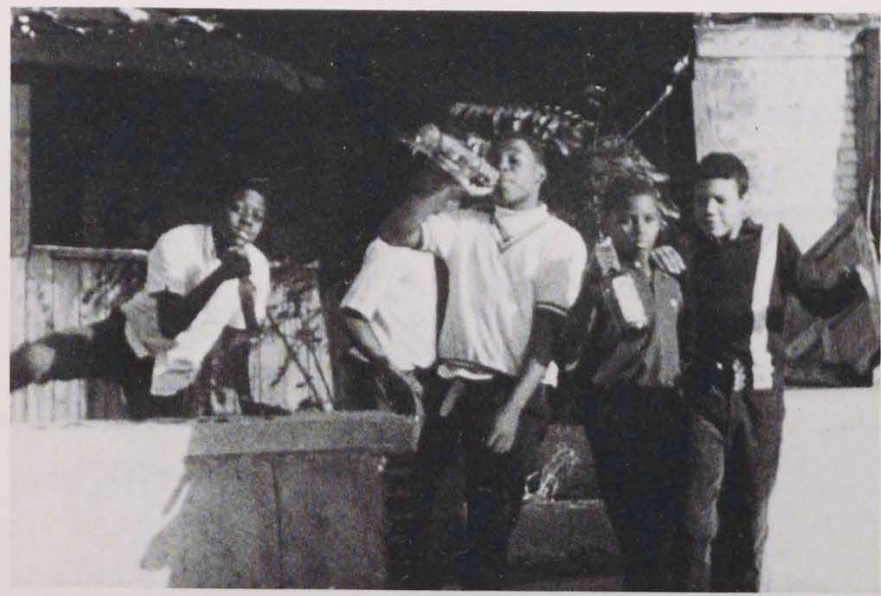

Illustration 10
1112 When SP I filmmaking groups had to decide where they wanted to shoot their practice films, they immediately chose a familiar neighborhood environment. Graffiti-covered walls in these areas often included names of the filmmakers. In contrast, the SP II groups preferred simply to shoot their films where we regularly met.

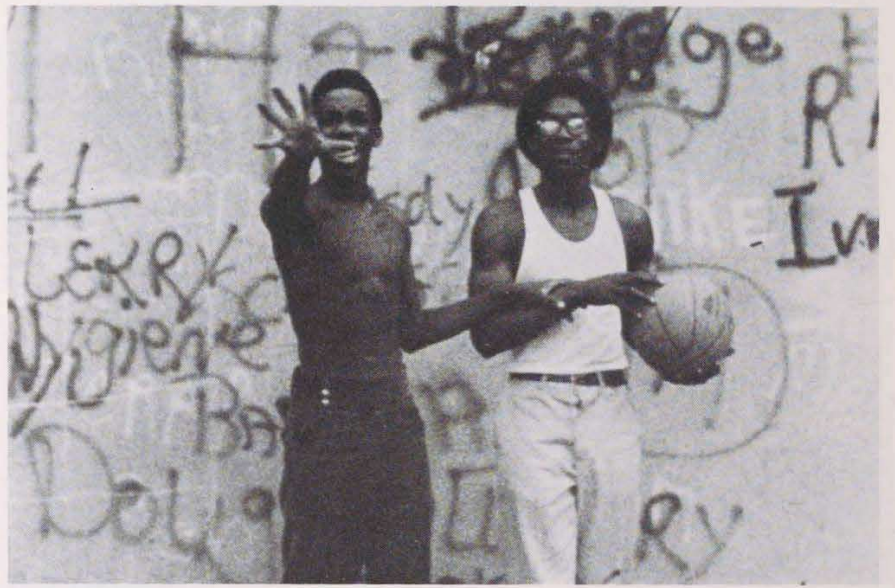

\section{Illustration 11}

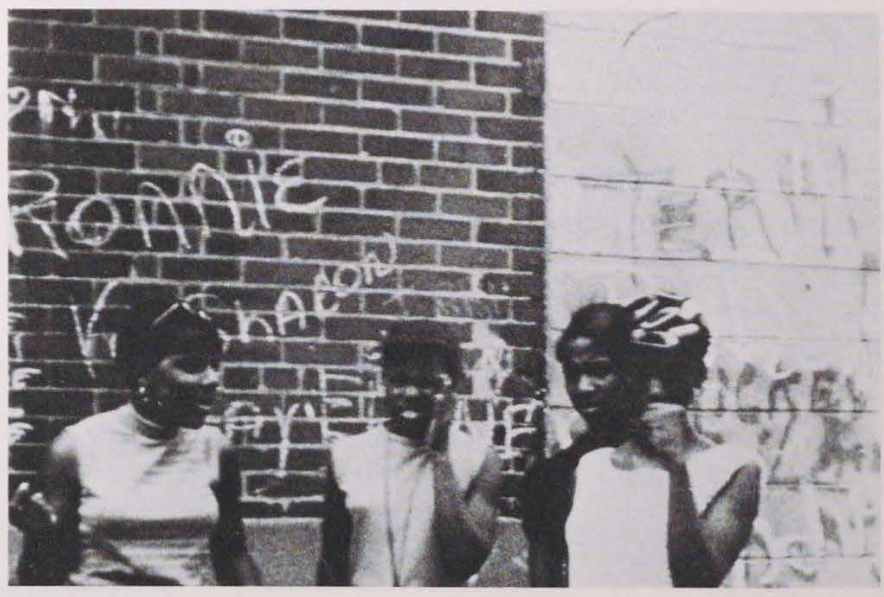

Illustration 12 


\section{Stable Pattern II: Characteristics of White Middle-Class Filmmaking}

(a) Stable Pattern II filmmakers spent nearly equal amounts of time in planning, filming, and editing. Their planning was characterized by lengthy and "heavy" discussions and controlled arguments regarding ways to make a movie. They tended to ask a lot of technical questions on the potential and limitations of the filmmaking equipment. Members of these groups found it difficult to settle on one idea for their film during their planning sessions. They preferred not to let one group member decide what the film would be about. SP il filmmakers were hesitant to commit themselves to one idea in any kind of written form.

(b) Stable Pattern II groups were very anxious to begin shooting; they did not feel that their films had to be completely outlined before beginning to use the cameras.

(c) For these filmmakers, less time was spent in filming than in either planning or editing.

(d) Stable Pattern II filming events were characterized by an avoidance of on-camera appearances. These filmmakers seldom put themselves in the movie. The majority of their filming attention was paid to behind-camera activity; they competed for use of the camera and sought praise for getting the "neatest" shots. SP II filmmakers emphasized testing the abilities of the camera and attended to image composition much more than any of the other groups. For groups in SP II, making a movie meant conceiving, shooting, and editing the movie and not being in the movie. They tended to deemphasize oncamera activity.

(e) In addition, the SP II groups tended to shoot much more film than SP I groups. These filmmakers tended to shoot a lot of film of the same subject matter, knowing that anything could be eliminated; they looked forward to the editing process.

(f) In Stable Pattern II, editing was treated as a very important event. There was a sense that this is where films were really made. Cutting and splicing was done by each group member in equal amounts. Slightly more time was spent in editing than filming and slightly less time than planning.

(g) Stable Patterns I and II are similar in that exhibition events received the least amount of attention.

In characterizing the components of Stable Pattern II, further contrast is seen to the behavior pattern outlined for Stable Pattern I. In terms of participants, the size of the SP II groups remained constant at four members instead of enlarging beyond five people.

None of these subjects were members of larger groups such as neighborhood gangs or social clubs. All group members generally contributed equally to planning, behind-camera filming, and editing events. Oncamera appearances by these filmmakers were very infrequent and much shorter than performances in Stable Pattern I. When these groups needed people in their films, they readily filmed strangers. In exhibition events, these filmmakers preferred audiences of strangers who would objectively evaluate their films rather than audiences of familiar friends and relatives.

Stable Pattern II filmmakers selected primarily rural and nonresidential settings within the urban confinements of the project. They displayed no desire to produce their film in local and/or familiar settings. Filming provided an impetus to visit and explore new locations.

Topics, themes, and activities selected by these groups usually involved nature, animal life, and, in some cases, inanimate objects. A recurring set of topics included sunlit leaves, branches, trees, birds, rivers or streams, and the like. SP II subjects never filmed themselves doing what they would "naturally" do. Their film themes involved their feelings about some subject of personal concern.

In terms of a message form, there was some reluctance to outline their film on paper (boys more than girls). There was no urgency in this matter since they felt that the film could be "made" in their editing sessions. SP II filmmakers gave little thought to the need for a storyline. Visually, the films contained few logical or distinguishable beginnings or ends. These filmmakers emphasized producing an original form for their movie; they preferred to make a film as visual art, that is, as an aesthetically pleasing, original, and intellectual statement.

Code characteristics of SP II movies included a lot of shot manipulation and frequent editing. These films contain many jump cuts, unnatural time and space juxtapositions, and sound tracks that are relatively independent of their visual tracks. High shooting ratios also characterize these movies. 
Illustrations 13-20

In contrast to the Stable Pattern I preference for filming scenes of human activity-usually of themselves-SP II filmmakers predominantly selected scenes of nature, architectural elements, and inanimate objects.

\section{Comparative Analysis of Event-Component Relationships}

Having stated the existence of two distinct and contrasting stable patterns (and before describing the unstable pattern), we can now examine sources and details of these findings. Specific examples of qualitative data will be explained using the sociovidistic framework of communication events and components. The richest sources of data are found in the pattern of X-marked cells in Table 3.

Ideally each of these important cells (relationships) would be examined for further similarities and differences that constitute the sociovidistic patterns under discussion. For the purpose of this abbreviated report, however, only examples of selected relationships will be discussed. Since both subcategories of Filming Events have emerged as very important events, being significantly related to four out of five components, the following discussion will be limited to these relationships. *

In the following analysis no attempt will be made to isolate the importance of individual sociocultural variables. Groups of varying sociocultural composition were used in part to provide a variety of examples of a film communication process. Data collected from this research simply do not bear the weight of a more rigorous analysis of individual variables such as ethnicity, socioeconomic status, and/or sex.

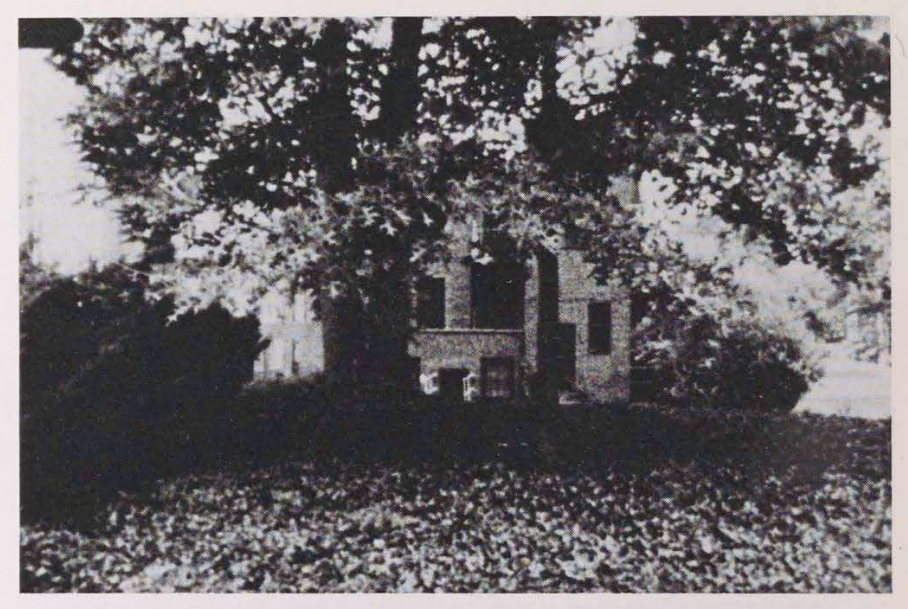

Illustration 13

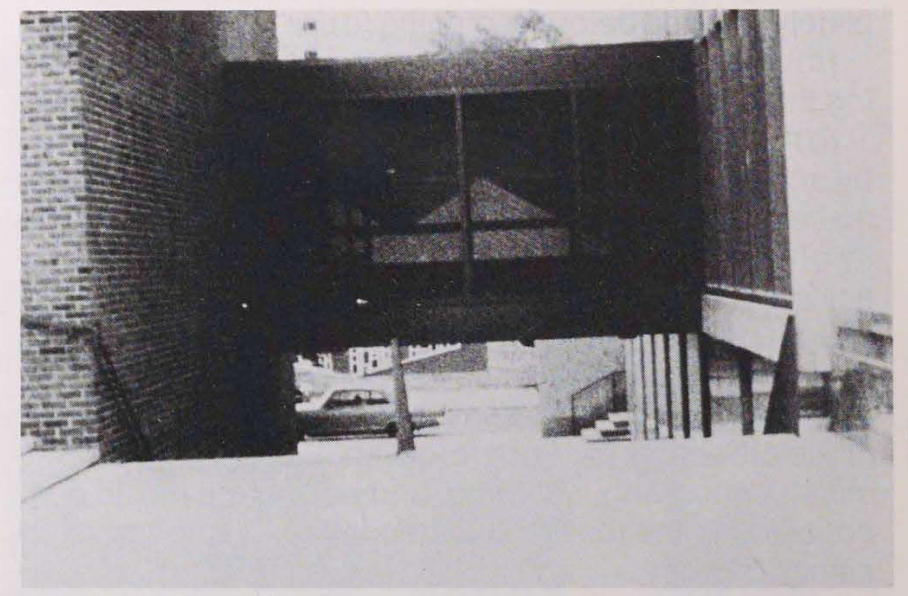

Illustration 14

Table 3

\section{Components}

Events

\section{Planning}

Filming on-camera

*Description, comparison and analysis of data comprising cell numbers 1,4 , $6,7,8,9,11,12,14,17$, 18 , and 19 can be found in Chapter 7 of Film as Visual Communication: A Sociovidistic Study of Filmmaking (Chalfen 1974).

\begin{tabular}{|c|c|c|c|c|c|c|}
\hline Planning & & & & & $x$ & \\
\hline $\begin{array}{l}\text { Filming } \\
\text { on-camera }\end{array}$ & 6 & 7 & 8 & & $x$ & 10 \\
\hline $\begin{array}{l}\text { Filming } \\
\text { behind- } \\
\text { camera }\end{array}$ & 11 & & & 12 & $x$ & 13 \\
\hline Editing & 14 & 15 & 16 & 17 & $\mathrm{x}$ & 18 \\
\hline Exhibiting & 19 & $x$ & 20 & 21 & & 22 \\
\hline
\end{tabular}


13-17 Frames taken from the practice films made by the white middle-class girls' group show a marked avoidance of human activity. More attention is given to image composition and finding unusual views, which, in turn, constitutes a "look-at-mesee" perspective. Scenes of nature and objects became important parts of their final film entitled God.

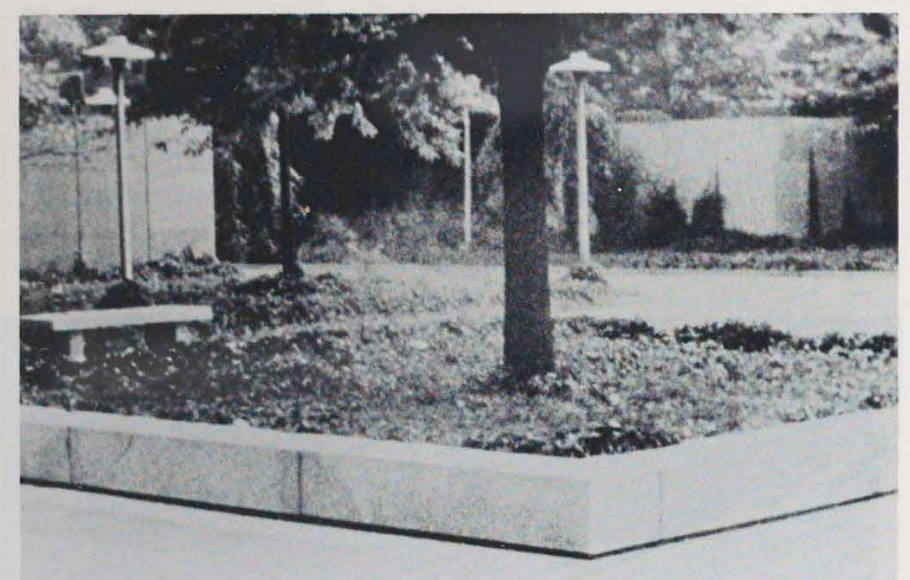

Illustration 15

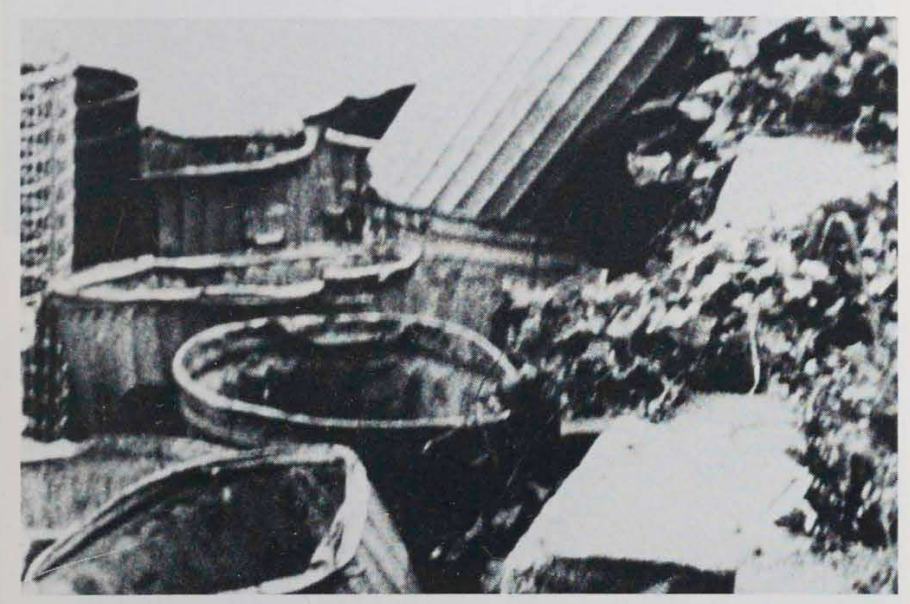

Illustration 16

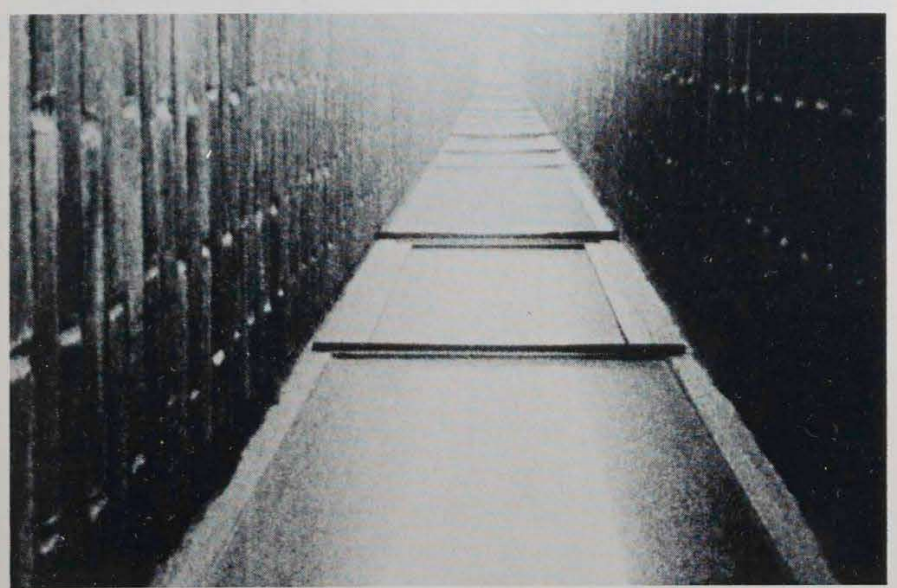

Illustration 17
18-20 When the SP II girls filmed people (only occasionally themselves) they would keep a person surrounded by scenery. The relationship of the person to the environment was more important than just the appearance of the person. In addition, they liked to film unknown people who were unaware of being photographed.

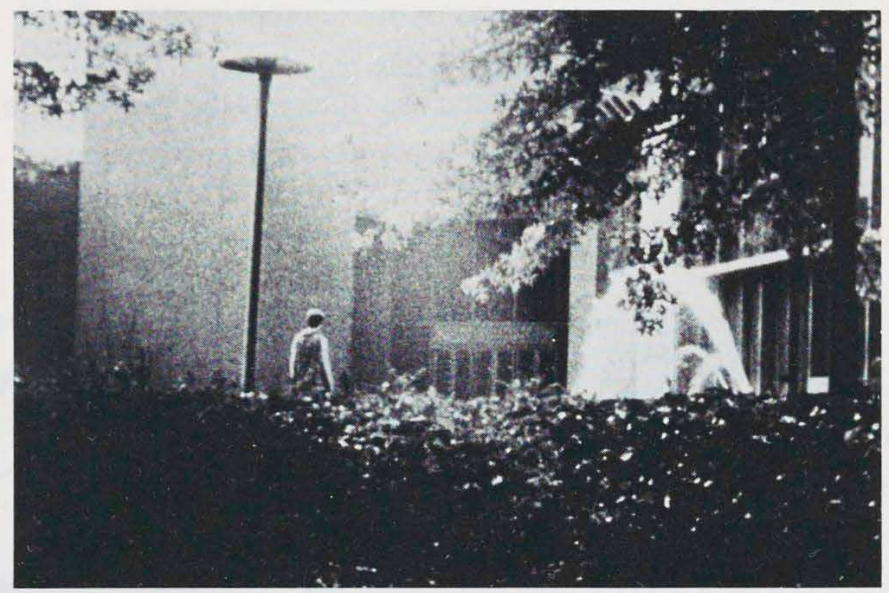

Illustration 18

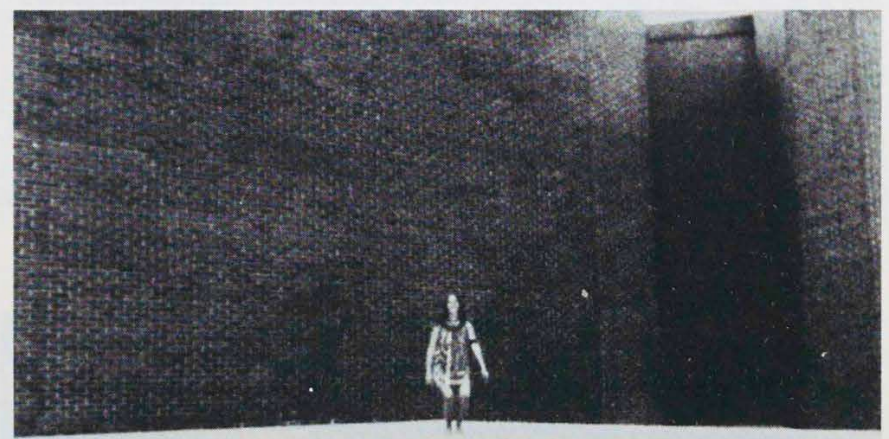

\section{Illustration 19}

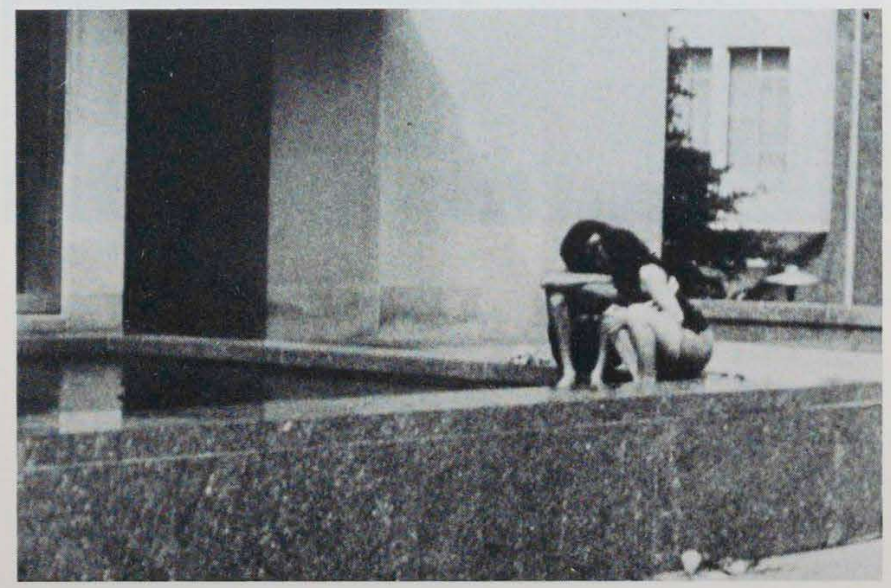

Illustration 20 


\section{Illustrations 21-28}

The other SP II group (white middle-class males) demonstrated a similar pattern of choices when making their outside practice films

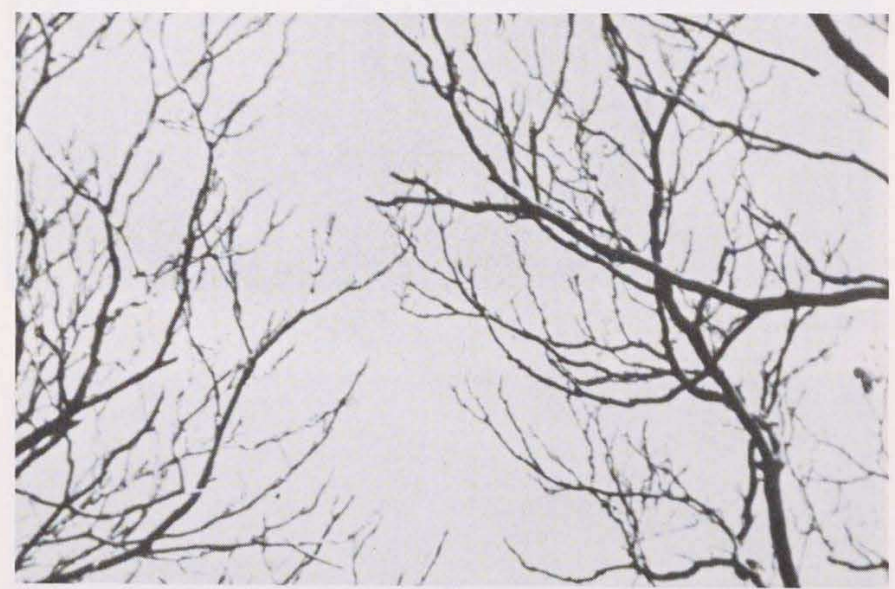

\section{IIlustration 21}

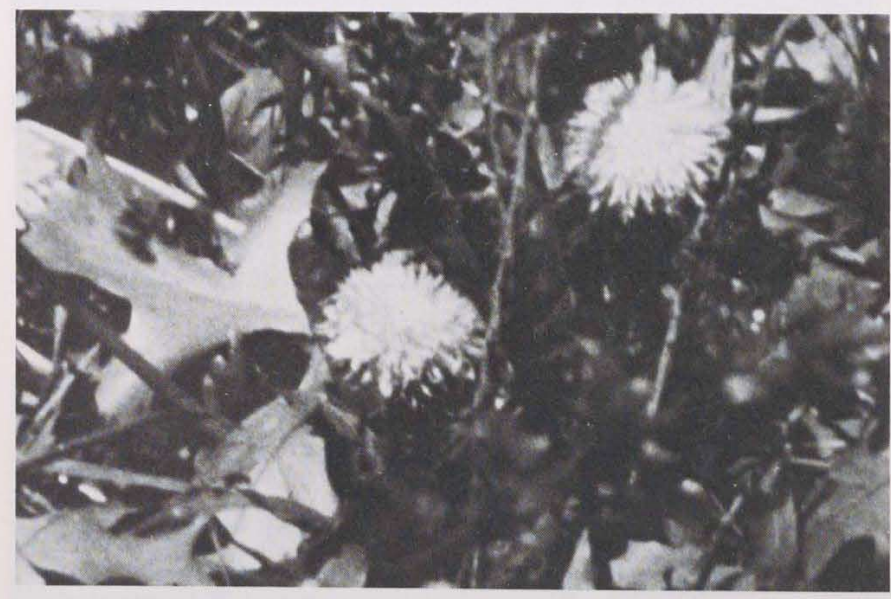

Illustration 22
21-24 Scenes from nature, architectural elements, and "interesting" objects were favorite on-camera subject matter. Scenes similar to these play an important role in their final film, entitled WPFG-M1. In contrast, SP I filmmakers never considered any of these topics.

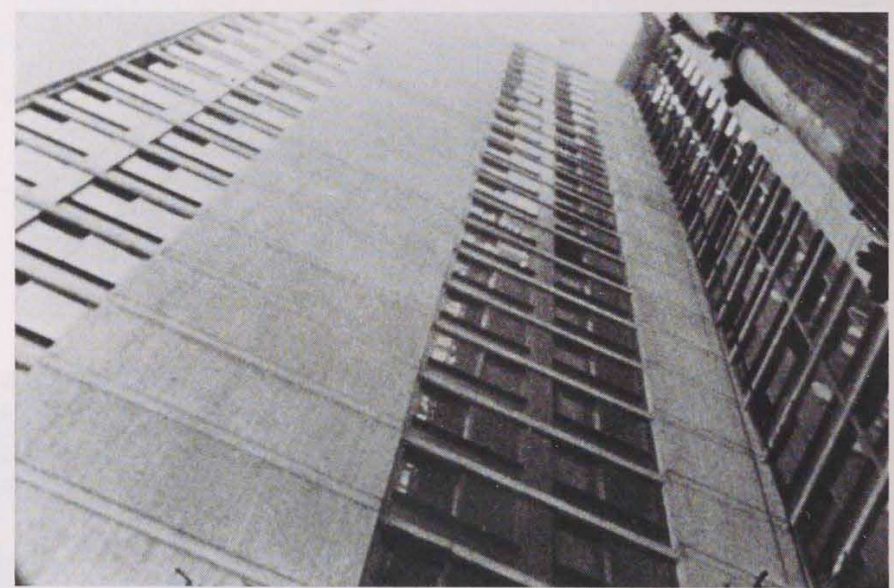

Illustration 23

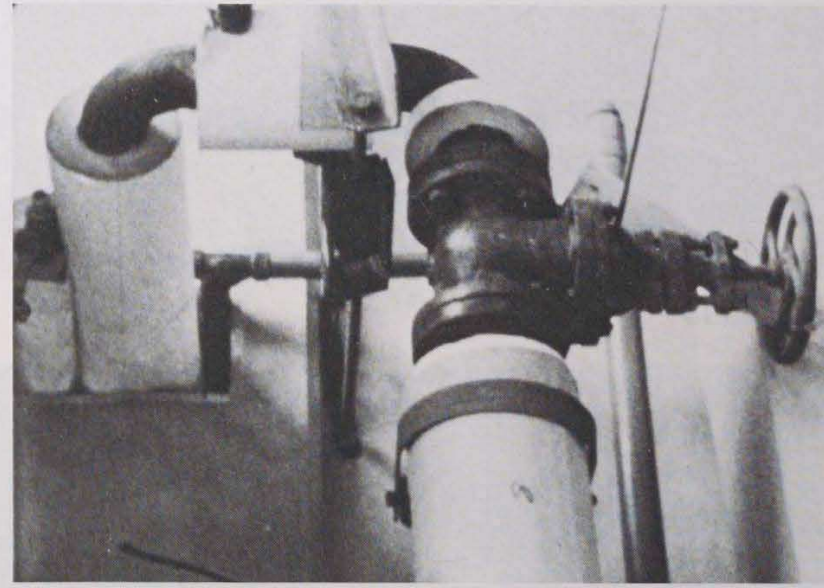

Illustration 24 
2526 In conjunction with finding unusual views, SP II teenagers sought to create unusual views by testing and manipulating the abilities of the camera. Shooting with the camera on an angle or changing the speed of the motor was done by both SP II groups in both practice and final films. In contrast, SP I groups were more interested in "straight" views.

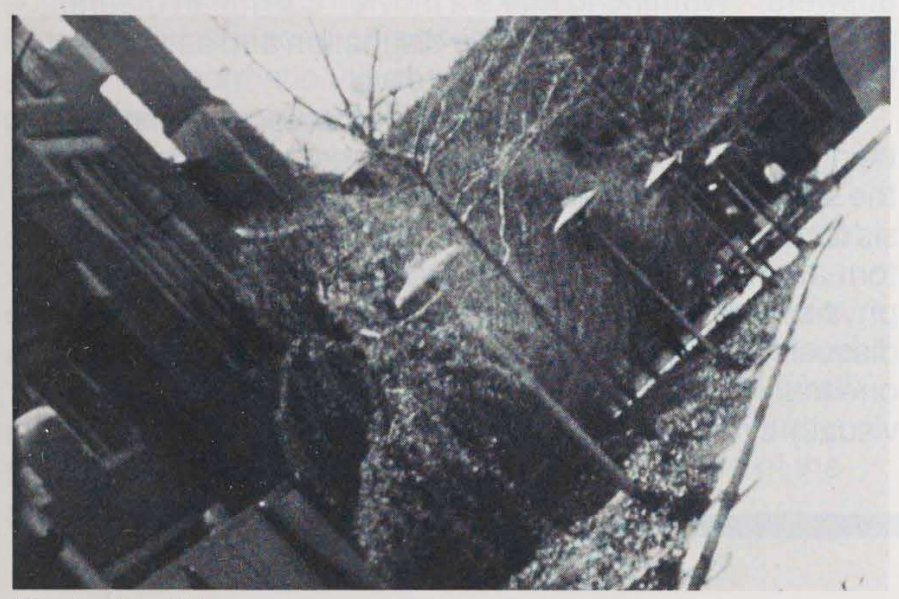

Illustration 25

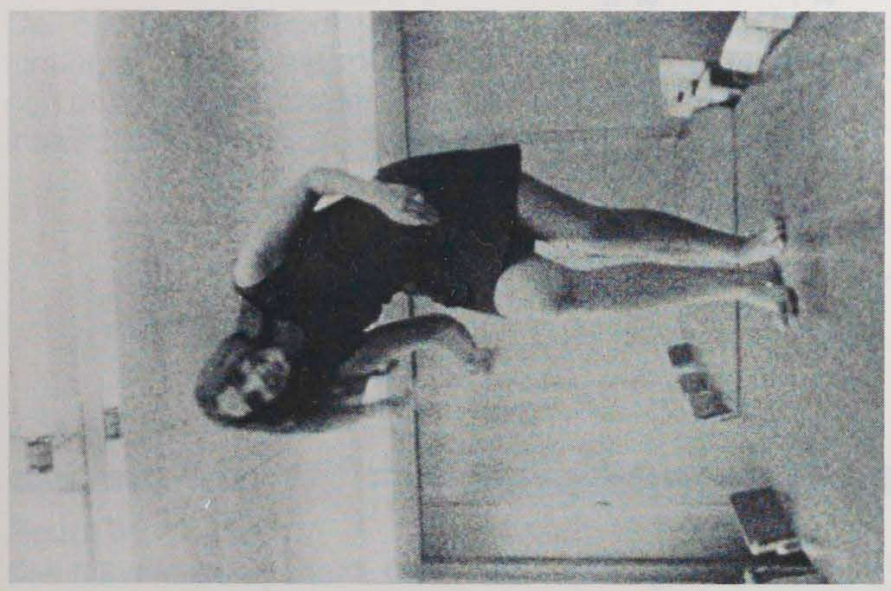

Illustration 26
2728 In most of the SP II practice footage, people tend to appear very small within the overall frame; backs of people are as likely to be seen as fronts. In contrast to the SPI results, the filmmakers are never seen as a group in the film. In the male SP II film we again see a person set in a particular environment. This contrasts with the SPI tendency to concentrate on just the person.

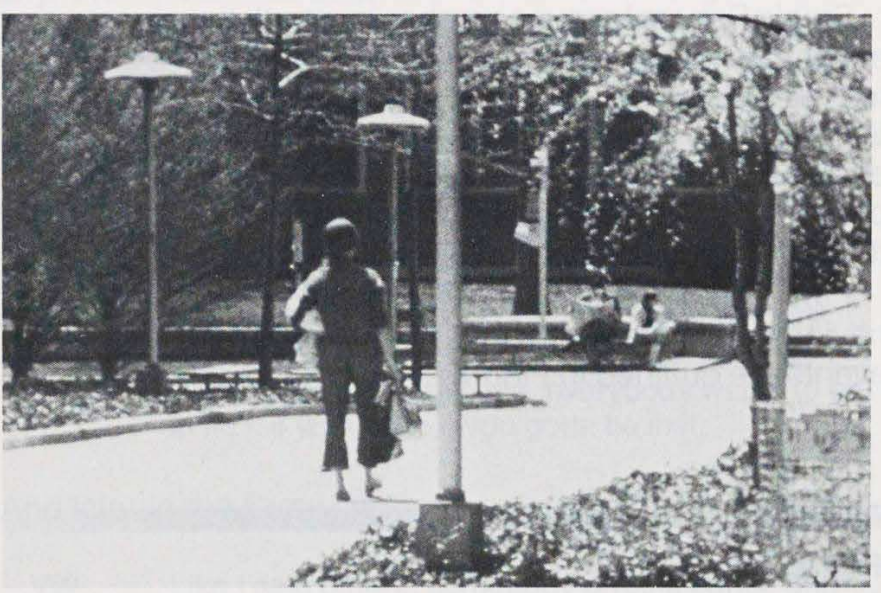

\section{Illustration 27}

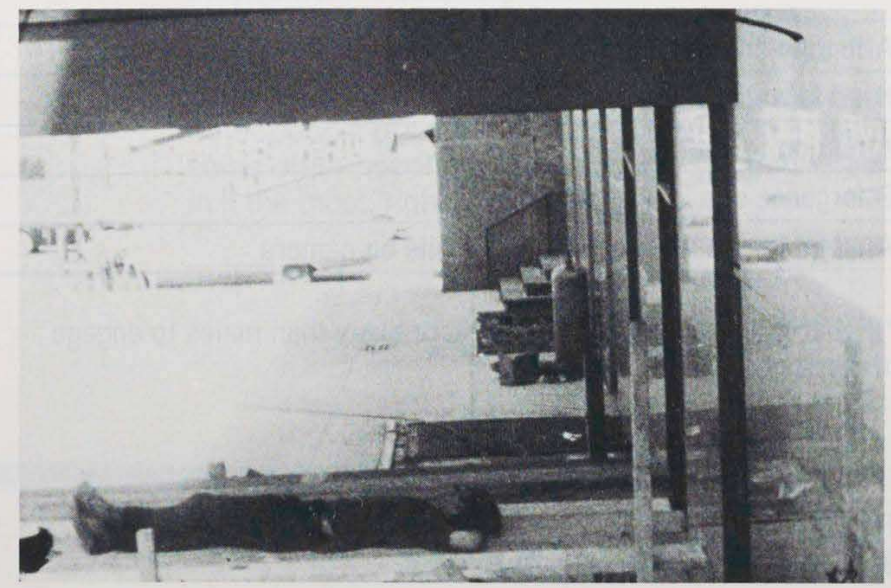

Illustration 28 


\section{Filming as a Communication Event}

As previously suggested, Filming as an event is too large a unit to work with. To report that a group emphasized "filming" ignores characteristics that potentially distinguish examples of a film communication process. Subcategories of "on-camera filming" and "behind-camera filming" immediately become relevant.

Stable Pattern I groups emphasized both the planning and the on-camera division of filming, whereas Stable Pattern II groups much preferred behind-camera filming activity as well as editing. SP I and SP II groups consistently emphasize different events in the film communication process. The recurrence and significant implications of this finding shall be discussed frequently in this analysis.

Further clarification and differentiation of filming behaviors associated with on-camera and behind-camera events are outlined in Figures 1 and 2.
The non-overlapping patterns of behaviors illustrated in Figures 1 and 2 are most striking and perhaps most significant in establishing two stable but different sociovidistic patterns. The on-camera/behind-camera distinction highlights a series of differences that are masked when we merely study "filming." To say that one group likes filming more than another raises more questions than it answers. "Wanting to make a movie" can mean different things to different people: the distinction and associated findings illustrate this point quite well.

By preferring to be and, in some cases, insisting on being on-camera, subjects are expressing a need to be the symbolic material of a filmic communication; emphasis is placed on using one's physical self to encode information. To be on-camera means that images of one's physical self will directly be the center of attention and discussion at a later time. Value is placed on how well one manipulates one's on-camera presentation as the visually symbolic material.

\section{Figure 1}

\section{On-Camera Filming Activities}

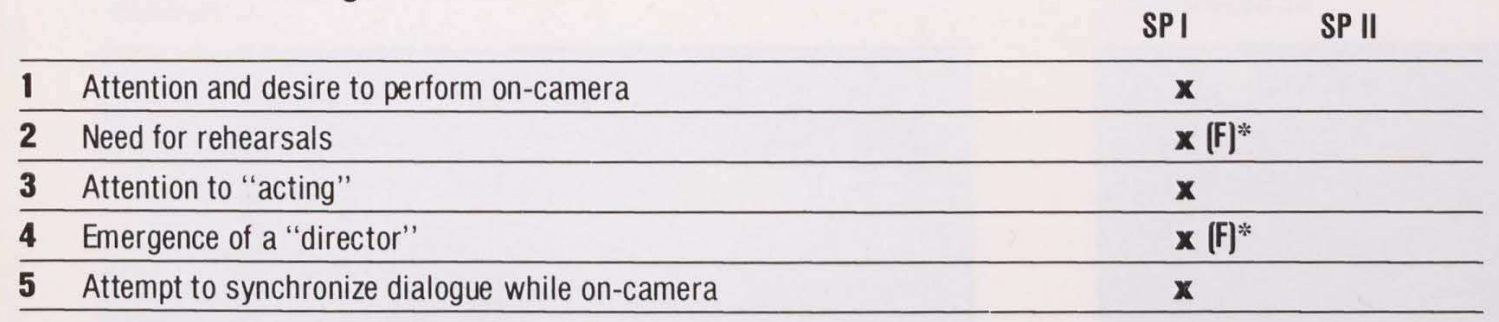

* $(F)$ indicates that females were more likely than males to engage in the specific behavior listed.

\section{Figure 2 \\ Behind-Camera Filming Activities}

SPI SP II

1 Attention and desire to use and operate camera and/or equipment

2 Attention to manipulating and/or testing abilities of camera

3 Need for retakes

4 Compete to get "best" or "neatest" shots $\quad$ X 
By preferring, on the other hand, to be behind-camera, and only infrequently on-camera, subjects are expressing a need to manipulate a different set of symbolic materials in filmic communication. Subjects became very selective in their filming of specific bits and pieces of the environment; they also chose to manipulate the recording of the visual material in terms of distorting motion, action, focus, horizontal and vertical axes, and so on. Emphasis was placed on encoding technique and manipulating information in an "artistic" manner. Value was placed on what one could do with the recorded images rather than as the recorded image.

Being black, being poor, and wanting to appear oncamera in contrast to being white, middle class, and not wanting to appear on-camera are important when we consider the unexamined claim that our young people are a "visual generation" (McLuhan 1964; Youngblood 1970) and that visual communication is a more natural mode than a verbal one (Arnheim 1969). My research findings indicate that, in actuality, not all sectors of the population feel this way.

\section{On-Camera Filming Events and Components}

Cell 6 in Table 3 represents the interaction of on-camera filming and the component "participants." A comparison of behavioral characteristics that characterize this interaction appears in Figure 3.
The clearest distinctions between Stable Patterns I and $I$ are seen in items 1,2, 3, 4, 5, and 8 . The black lower-class groups thoroughly enjoyed performing oncamera, and extra people joined the group for this activity. The consistent tendency of these groups was to film people, but not any group of people. They restricted the on-camera participants mainly to themselves; occasionally, their close friends and Chalfen were included.

There were many indications of the Stable Pattern I preference to appear on-camera. During one of the introductory sessions, the following discussions took place with the group of SP I girls.

Chalfen: And then you've got to figure out who might be in it-who will be in the film.

Haley: You pick the people in it.

TM: Me, I want to be in it (a couple of the other girls say, "Me, too.").

VW: $\quad$ All five of us want to be in, everybody wants to be in it... if you make it you gotta be in it.

And later in the same session:

VW: Like I said before, somebody gives a dance and we invite the people, a party rather and show how they (different couples) met. .

Haley: Well are you gonna throw a dance and let them meet this way?

VW: Uh huh. A play dance-just with us in it and a few other people but they're not going to be in it, just some other people for background. We gonna be in it the most, right?

\section{Figure 3}

\section{Cell 6 Event-Component: On-Camera Filming- Participants}




\section{Figure 4}

\section{Cell 7 Event-Component: Filming-Setting}

Characteristics

SPI

SP II

\begin{tabular}{lllc}
\hline $\mathbf{1}$ & Filming inside home of filmmakers & & $\mathbf{X}$ \\
\hline $\mathbf{2}$ & In neighborhood of filmmakers & $\mathbf{X}$ & $\mathbf{X}$ \\
\hline $\mathbf{3}$ & In urban-residential areas & & \\
\hline $\mathbf{4}$ & In rural-urban nonindustrial nonresidential areas & $\mathbf{X}$ & \\
\hline $\mathbf{5}$ & In areas where filmmakers were known & & $\mathbf{X}$ \\
\hline $\mathbf{6}$ & Restricted use of settings & $\mathbf{X}$ & \\
\hline $\mathbf{7}$ & Frequent changes in settings & \\
\hline $\mathbf{8}$ & Tendency to arrange setting before filming &
\end{tabular}

\section{Figure 5}

\section{Cell 8 Event-Component: Filming-Topics}

\section{Characteristics}

\begin{tabular}{llll}
\hline $\mathbf{1}$ & Frequent appearance of people in films & $\mathbf{X P I}$ & $\mathbf{X}(\mathrm{M})^{*}$ \\
\hline $\mathbf{2}$ & Avoidance of using people in films & $\mathbf{X}$ & \\
\hline $\mathbf{3}$ & Use of people acting and aware of an operating camera & & $\mathbf{X}$ \\
\hline $\mathbf{4}$ & $\begin{array}{l}\text { Use of people seen in "natural" behaviors unaware of } \\
\text { operating camera }\end{array}$ & $\mathbf{X}$ & \\
\hline $\mathbf{5}$ & Frequent attention to sports activity & $\mathbf{X}$ & $\mathbf{X}$ \\
\hline $\mathbf{6}$ & Frequent attention to fighting activity & & $\mathbf{x}$ \\
\hline $\mathbf{7}$ & Frequent scenes of dancing, drinking and/or smoking & & $\mathbf{X}$ \\
\hline $\mathbf{8}$ & Frequent use of scenes of nature and animals & & \\
\hline $\mathbf{9}$ & Frequent appearance of inanimate objects & & \\
\hline
\end{tabular}

*(M) indicates male tendency

The white middle-class groups did not emphasize putting themselves in the movie; they preferred to film unknown people when they required some form of human activity. Thus, Stable Pattern I is characterized by the filming of the filmmakers themselves and their friends, whereas SP II filmmakers infrequently filmed themselves, never filmed their friends, and preferred to shoot unknown people.

Cells 7 and 8 in Table 3 are collapsed cells representing the relationships of both "on-camera" and "behindcamera" filming events with the "settings" component (Cell 7) and with the "topics" component (Cell 8). These cells are integrated because the setting or location of one event almost always coincided with the setting or location of the other event. A similar overlap was noticed for the topic component.

Additional differences betweeen SP I and SP II are evident when we examine the data for Cells 7 and 8 .

Summarizing the data for Cell 7 we see that SP I groups were more likely to select a local and familiar setting in their neighborhood but not so intimate a zone as their own homes. In contrast, SP II groups tended to ignore both their homes and neighborhoods in favor of quasi-rural settings that were usually some distance from their neighborhoods.
An unexpected dimension of filmmaking behavior emerges to differentiate the two patterns. Differences for findings on the use of local and familiar vs. nonlocal and unfamiliar settings (see Figure 4) and the use of known and familiar vs. unknown and unfamiliar on-camera participants (see Figure 3) appear to be consistent for Pattern I and Pattern II groups respectively.

Referring to Cell 8, while the different subject-filmmakers could have filmed almost any set of topics, activities, or events, it appears that five of the eight groups did not select a vastly divergent array of subject matter. The data indicate that topic selections of the five groups can be neatly arranged into two relatively uniform patterns, which, in turn, correspond to two socially defined filmmaking contexts. Thus the existence of two stable sociovidistic patterns is further strengthened.

The first four items listed for Cell 8 in Figure 5 are closely related to findings reported for Cell 6 , which represented the relationship of "participants" and "oncamera filming." In the latter instance, we were asking "who" appeared in the sociodocumentary films; in Cell 8, when people are listed as a topic, we are more concerned with "how" people are shown and the context of human activity. However, the component "topics"' is not restricted to people. 
Item 1 in Figure 5 is interesting in that all groups showed people in their films at some point. However, the groups greatly differed with respect to how people were shown, how human activity was emphasized, and, in some cases, how it was avoided.

One general finding is that all three black lower-class groups in SP I show people in nearly every shot of their practice and final films. The people may not always be the filmmakers themselves, but some form of human activity is consistently shown. The white middle-class groups of SP II, especially the male group (see item 2, Figure 5), tended to avoid filming people or treated the human image in equal importance to either animal life or inanimate objects (see items 8 and 9, Figure 5).

A lack of interest in filming humans, human activity, and/or human products was carried to an extreme by the male SP II group. Information on this topic restriction came out during a discussion during their 28th session, on the use of a shot with a person in it.

\footnotetext{
DR: "Jetty and People," [reading from a shot list] do we have that in there? Number 7 ?

TM: "Jetty and People," what's that? Is that checked, Chuck?

CM: $\quad$ Yeah [meaning it is still in film].

DR: $\quad$ Take it out.

Chalfen: Isn't that the one where one or two people walk down on the jetty?

CM: Could I see, what does it look like?

TM: $\quad$ We can't use it; it's got people in it anyway.

DR: I know.

CM: $\quad$ All right. Use number 9. Even though there is Tim in it, it's probably one of the prettiest shots there.

Chalfen: People can't be in it because they are produced?

TM: $\quad$ Well let's put it this way, Dick, we've set rules, but what we'll do is, uh, the rules are flexible. All right?

Chalfen: What is one of the rules? What do you mean; I don't understand what you mean by rules.

TM: $\quad$.... no people, no man-made things, no cars; well the thing is that what we also mean by "manmade," another way of putting that would be, you know, ugly, protruding, you know, and it happens that person there, it is a very pretty shot with that person there, with the sun coming along behind.

CM: It's actually as though he's not really alive.

TM: $\quad$ Yeah... I would keep it in; I really don't know where it will fit into our film.

CM: I would keep it in too... I think it's the prettiest shot there.
}

So, in discussing a "violation" we learn more about the norms, or "rules," that have been imposed on topic selection. It appears that humans were appropriate as long as they don't look "alive."

Thus, again, we see that what could have been a very diverse and heterogeneous choice of subject matter appears also to have a nonrandom and structured quality.
The last component relevant to on-camera filming events, in a sociodocumentary context, is "message form." The general concern of this event-component relationship (represented in Cell 9) is how the subject matter, as arranged in front of an operating motion picture camera, becomes the message form of the film itself. This information contrasts with appropriate data for Cell 12, which examines how the message form may be structured by behind-camera activity, in which cases the visual content of a film is more a result of camera manipulation than the stream of behavior that occurred in front of the camera.

\section{Characteristics of Cell 9 are outlined in Figure 6.}

While Cell 9 is not very rich in data, the distinctions between items 1, 2, 3, and 4 and the findings for item 5 are particularly important, though not too surprising.

In light of earlier findings for Cells 6 and 8 (see Figures 3 and 5), and the next findings for Cell 11 (Figure 7 ), it is logical that we see Stable Pattern I filmmakers preferring to use the presence and activity of their own bodies as the focal point of their message forms. In many respects, these young people are metaphorically asking to be looked at for the integrity and importance of themselves. In this sense, the meta-message of this message form is "look at me."

In contrast to this perspective, for the white middleclass filmmakers, the focal point of scenes using people (who were usually not the filmmakers) was a juxtaposition of people within a specific environment. In most cases, this was a "found" relationship rather than a staged one. Thus, the meta-message of these message forms is "look at me see."

\section{Behind-Camera Filming Events and Components}

It appears that behind-camera filming events are equally as important as on-camera events but for quite different reasons. Both types of filming events have four relevant component interactions, and, as previously noted, two cells are "held" in common. Relevant relationships shall be discussed in analysis of Cells 11 and 12 .

Cell 11 represents the relationship between the "participants" component and "behind-camera" filming events. The general concern is who was involved in the use of the camera and related filming apparatus, and the behavior of the group while this event took place.

Findings for Cell 11 are important in further presenting evidence for the two stable but different patterns of sociovidistic behavior. Whereas SP I groups enlarged during filming events, it was obvious that the interest and enthusiasm was for on-camera participation and not behind-camera participation (see item 1, Figure 3). It became clear that the interest of SP II groups was more 
concentrated on behind-camera filming, but they did not allow extra people to come to their sessions for this reason (see item 1, Figure 7).

Items 2 and 3 of Figure 7 illustrate an interesting reciprocal relationship between filming attitudes expressed by subject-filmmakers from the two stable patterns. Members of the black lower-class groups hoped that someone in the group would take over the technical matters and want to do the actual filming. Use of the equipment was a low-priority activity when compared to an opportunity to be on-camera (see Figure 3 ). The excitement of "making a movie" did not include an enthusiasm for behind-camera activity after the initial learning and practice were completed.

Oneanswer to the disinterest in filming appears in item 5; these groups asked Chalfen to film the movie for them. But while SP I groups would ask Chalfen to use the camera, neither they nor any other group in the research asked an outsider to shoot their movie (see item 4).

Characteristic behavior of SP II for Cell 11 sharply contrasts with attitudes and behavior that have been outlined for SP I. Instead of having difficulty getting any one group member to do the shooting, members of the white middle-class groups insisted that each person have an equal opportunity to use the equipment and to film in his or her preferred manner. There was an implicit agreement that behind-camera duties were to be shared equally; one group member could not become "numberone cameraman.'

For Stable Pattern II groups, behind-camera filming was a high-priority activity in "making a movie." Field notes from the 11 th session of the boys' group read as follows.

One point was very striking to me today. In terms of what I have called "the shooting event" [now called "behindcamera filming events" $]$, it is very clear that the emphasis of these boys is on what the camera does and what the shot looks like. There is a lot of value placed on shooting and composing the images. At times, I saw all 4 boys behind the camera, huddled, trying to see how it was going to look. ... This is just opposite from the black filmmakers who each demanded to be in the footage, and often neglected to leave someone to shoot the film.

\section{Figure 6}

\section{Cell 9 Event Component: On-Camera Filming-Message Form}

\begin{tabular}{llcl} 
& Characteristics & SPI & SP II \\
\hline $\mathbf{1}$ & Presentation of self (usually the filmmakers) as message form & $\mathbf{x}$ & \\
\hline $\mathbf{2}$ & Rehearsals of on-camera presence & $\mathbf{X}$ & \\
\hline $\mathbf{3}$ & Use of costumes, makeup, props, etc. & $\mathbf{x}$ & \\
\hline $\mathbf{4}$ & Focus of attention is behavior of person(s) on-camera & $\mathbf{x}$ & \\
\hline $\mathbf{5}$ & $\begin{array}{l}\text { Focus of attention is relationship between people and } \\
\text { surroundings that appear on-camera }\end{array}$ & & $\mathbf{X}$ \\
\hline
\end{tabular}

Figure 7

Cell 11 Event-Component: Behind-Camera Filming-Participants

Characteristics

SPI

1 Original size of group enlarges because of behind-camera filming

\begin{tabular}{llll}
\hline $\mathbf{2}$ & Attitude: Any group member does filming & $\mathbf{x}$ & $\mathbf{x}$ \\
\hline $\mathbf{3}$ & Attitude: Every group member does filming & & \\
\hline $\mathbf{4}$ & Outsider asked to do filming & $\mathbf{x}$ \\
\hline $\mathbf{5}$ & Chalfen asked to do filming & \\
\hline
\end{tabular}




\section{Figure 8}

\section{Cell 12 Event-Component: Behind-Camera Filming-Message Form}

\begin{tabular}{|llcc} 
& Characteristics & SP I & SP II \\
\hline $\mathbf{1}$ & Tendency to shoot film in the sequence prescribed by script or outline & $\mathbf{x}$ & \\
\hline $\mathbf{2}$ & Tendency to shoot film "out of sequence" & $\mathbf{X}$ & \\
\hline $\mathbf{3}$ & Simple use of camera technology & & $\mathbf{X}$ \\
\hline $\mathbf{4}$ & Elaborated use of camera's abilities & $\mathbf{x}$ & \\
\hline $\mathbf{5}$ & Preference for long camera takes of fabricated scenes & & $\mathbf{X}$ \\
\hline $\mathbf{6}$ & Preference for short camera takes of "natural" scenes & $\mathbf{x}$ & \\
\hline $\mathbf{7}$ & Camera used to produce a record or copy of reality & & $\mathbf{X}$ \\
\hline $\mathbf{8}$ & Camera used to collect, distort, and manipulate imagery & \\
\hline
\end{tabular}

Later in my notes from the same session:

There was an emphasis placed on finding the best shot. Remarks included: "Oh, that's pretty ... shoot it! ... Chuck's got one... No, Dave's is better...." Again the emphasis was on getting the camera to do neat shots. This was really in the form of excitement. Whereas I used to have trouble keeping everybody interested in what was going on while only one person could use the camera at a time(Pattern I groups), these boys were always finding things to check up on or in looking for the next shot. At one point I heard "the setting-up staff' ' mentioned. They were in charge of the camera placement, f-stop and the focus. Each one [member of the group] would check the shot. Alot of cooperation indeed.

It is very significant that SP II groups stressed the "recording" aspects of moviemaking rather than "being recorded." The meta-message of their film communication, expressed as "look at me see," is again evident.

The second important event-component included in behind-camera filming is represented by Cell 12. In the relationship of "message form" and "behind-camera" filming, we are concerned with how the message form of the film is primarily structured by specific ways of using the camera. Behavioral characteristics of this relationship are outlined in Figure 8.

Findings for Cell 12 reaffirm several SP I-SP II differences and are internally consistent with findings reported for other cells. Stable Pattern I groups were more likely to produce a story line, and their behind-camera activity chronologically followed time sequences according to the story line. Stable Pattern II groups, less likely to develop a story line, preferred to film different "sections" or "scenes" of their films according to needed settings that were easily accessible and convenient. Thus, SP II groups favored shooting their film out of sequence, if a sequence had been determined during planning.

SP I and SP II differences found for items 3 and 4 are a logical extension of attitudes toward filming reported in both Cells 6 and 11 (Figures 3 and 7). The groups that attended more to on-camera performance (SP I) tended to simplify the use of the camera by using it primarily as a recording or copying device (see items 3 and 7). For these groups, individual shots were frequently the length of a full camera wind and contained scenes of prearranged, and often rehearsed, settings and / or sequences of acting (see item 5).

Stable Pattern II groups, on the other hand, in attending to behind-camera activity, tended to elaborate and exploit the camera's potential. In doing so, they preferred to make short shots, sometimes as brief as a few frames, which were frequently composed as still life images. In collecting sequences of these short shots, the camera was also used to distort the imagery by changing the speed of the camera, changing the focus, or running the camera on its side or upside-down (see item 8).

Findings reported in Figure 8 allow us to extend our thinking on the SP II preference for manipulating units of symbolic material. Findings reported in response to questions raised by this event-component offer visible manifestations of this preference as well as a comparative paradigm of opposite behavior characteristic of SP I filmmaking 


\section{Unstable Pattern III (USP III)}

It remains to reapply the sociovidistic framework to examine the filmmaking projects of three other groups that now comprise Unstable Pattern III. Subjects in these groups come from black middle-class and white lower-class backgrounds (groups 6, 7, and 8 in Tables 1 and 2). Groups have been included in USP III because distinct changes were observed in their filmmaking process and not because all the changes were the same. For instance, the subjects could change their choice of shooting locations, themes, or topics for the film; they could reorganize themselves for shooting, acting, or editing the film; or they could rewrite and reshoot sequences of action.

In retrospect, it appears that the three USP III groups either "borrowed" traits or shifted between traits identified as characteristic of either Stable Pattern I or Stable Pattern II. Relatively few new behavioral traits were introduced in the analysis of USP III. Specific examples will make this clearer. Analyzed event-component relationships will again be limited to activities associated with filming events.

\section{USP III Filming Events and Components}

Several relevant examples of behavioral shifts occurred during the filming events of the black middle-class girls' group (see Group 8, Tables 1 and 2). On-camera and behind-camera behavior changed during the making of their practice films. The four girls began their outside practice footage by enthusiastically shooting nearly all 200 feet of film on scenes of themselves in short oncamera skits. Many scenes included themselves posing and looking directly at the camera. In terms of the behavioral characteristics outlined for Cell 6 (see Figure 3), this group exhibited a strong tendency to film people, using themselves as participants in on-camera events. They also filmed Chalfen but generally avoided filming people who were unknown and/or outside the film group (see items 3, 4, 7, and 8 of Figure 3 ). According to these results, this group initially conformed to the sociovidistic behavior of Stable Pattern I.

However, when the rushes of this practice film were first seen, the girls were quietly upset. They were unhappy with what they saw, and two girls were noticeably embarrassed. After their second session of practice shooting, the girls verbalized a dislike for being in the movie so much of the time:

Chalfen: Well, listen, I think you liked this 200 feet better than that first 200 feet.

CM: You know why? ... We weren't really, we weren't in it as much as the other one, we were really in that one.

Chalfen: Yeah, that's true, you're not in this one as much.

CM: Well we were... But, everything but the faces.
The second practice footage made by this group looks very unlike their first efforts. People appear much less frequently, and there are only a few full body shots of members of the film group. Face-camera interactions are almost totally absent. This time, the girls tended not to use themselves as on-camera participants and were more willing to film outsiders or just headless bodies when they needed humans on-camera (see items 3, 4, and 8 of Figures 3 and 9 ). This remarkable change in the relationship between participants and on-camera events now conforms much more to characteristics of Stable Pattern II. This set of changes is illustrated in the righthand columns of Figure 9.

In other words, the filmmaking behavior of this USP III group, initially conforming to characteristics of the black lower-class groups, shifted toward the behavioral pattern characteristics of the white middle-class groups.

A shift in just the opposite direction was observed for another Unstable Pattern III group comprised of white lower-class girls (see Group 7, Tables 1 and 2). In their first practice footage, shot in a large park near a creek, they avoided filming each other as appropriate on-camera participants. Instead they used the telephoto lens to film people in different parts of the park. Their oncamera subjects neither knew the filmmakers nor were known by the filmmakers. The girls quickly panned over a vast area of trees, hills, parkland, and buildings across a street in order to film a mounted park guard, two young boys playing near a drain pipe, four people sitting under a tree smoking, and other people walking dogs or driving by in cars and busses.

In terms of behavioral items listed in Figure 3, it is significant that most of their on-camera participants were unknown people. Members of the film group were initially reluctant to be filmed and kept ducking away from the camera. This USP III group was first like SP II groups for item 2 (the size of the group remained the same), item 4 (they did not tend to film themselves), and item 8 (they did film unknown people). These girls were also like SP I groups only in item 3, the tendency to consistently put people in the movie.

However, this pattern of behavior significantly changed later in the same afternoon when the girls continued shooting their second 100 feet of outside practice film. They asked me to drive them to a local cemetery. Again, they concentrated their filming on people. This time, however, they almost exclusively filmed themselves in various oncamera skits. When the girls later saw the rushes of this footage they verbalized their shift in behavior. 
29-31 In the first practice film made by Group 8 (black middle-class girls) the teenagers enjoyed using themselves as on-camera participants-in scenes of group dancing, modelling, hamming for the camera, and short dramatic skits. Their first tendencies were to produce a Stable Pattern I model of moviemaking.

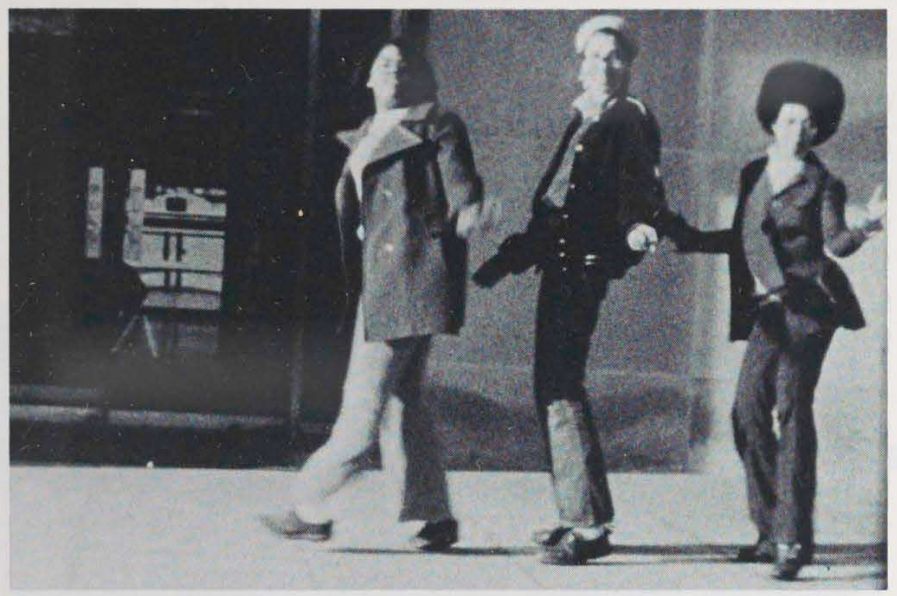

Illustration 29

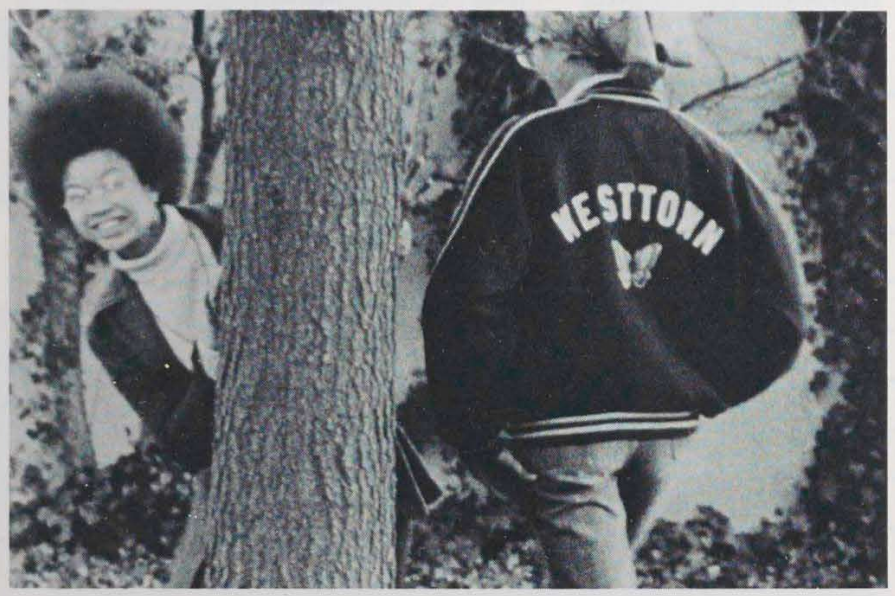

\section{Illustration 30}

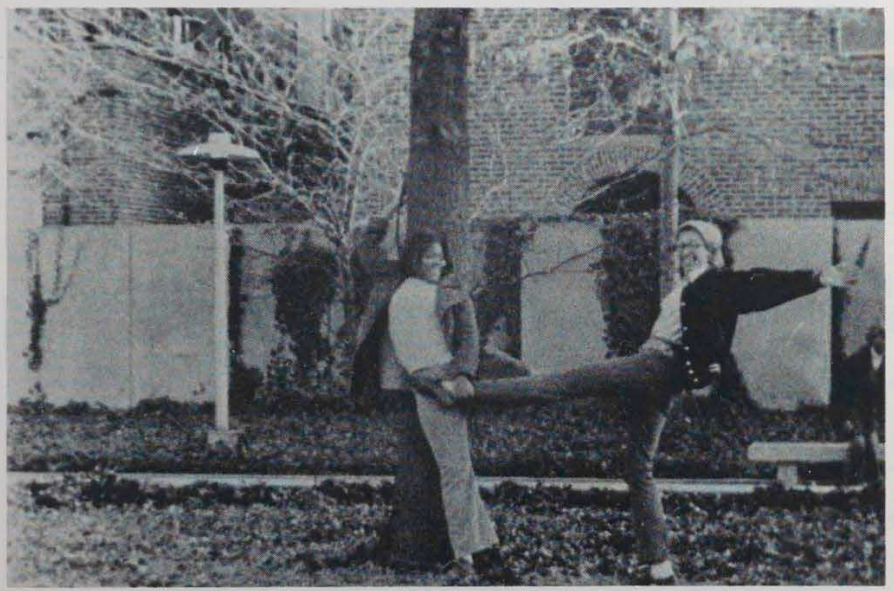

Illustration 31
32-34 The second practice film shot by Group 8 contained very few shots of group members posing for the camera. This time they much preferred to film interior scenery, objects, designs, and only body parts rather than whole people. They also began to manipulate the camera-creating slow motion and trick photography. Their changes were producing a version of Stable Pattern II, characteristic of white middle-class filmmaking.

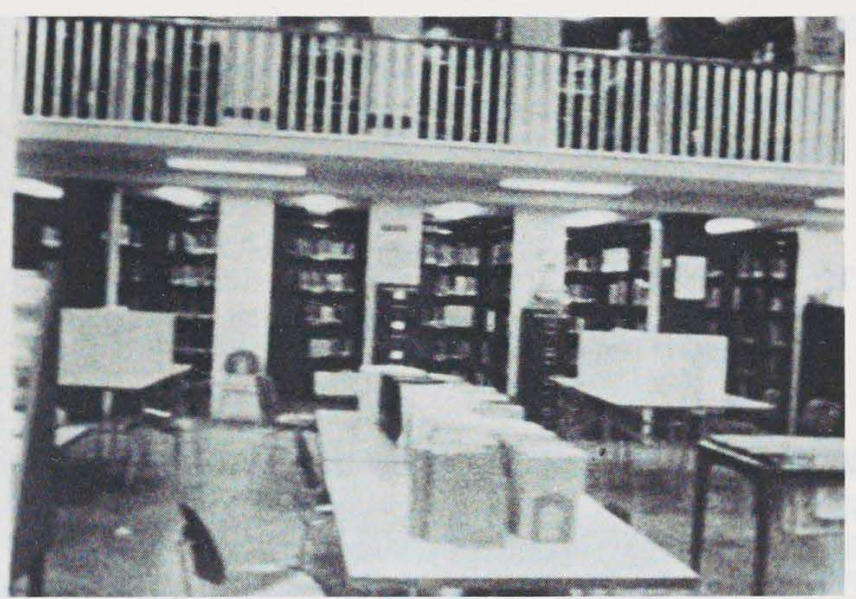

\section{Illustration 32}

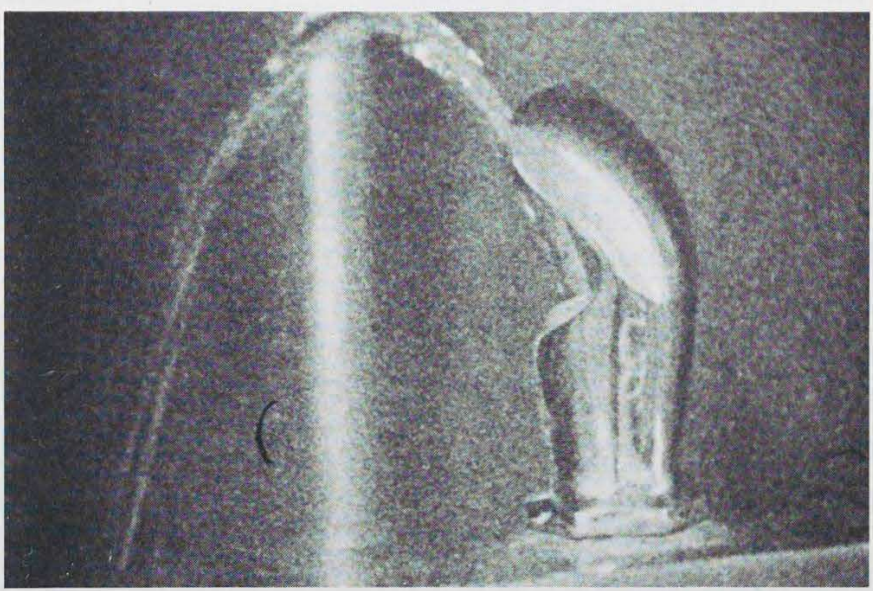

Illustration 33

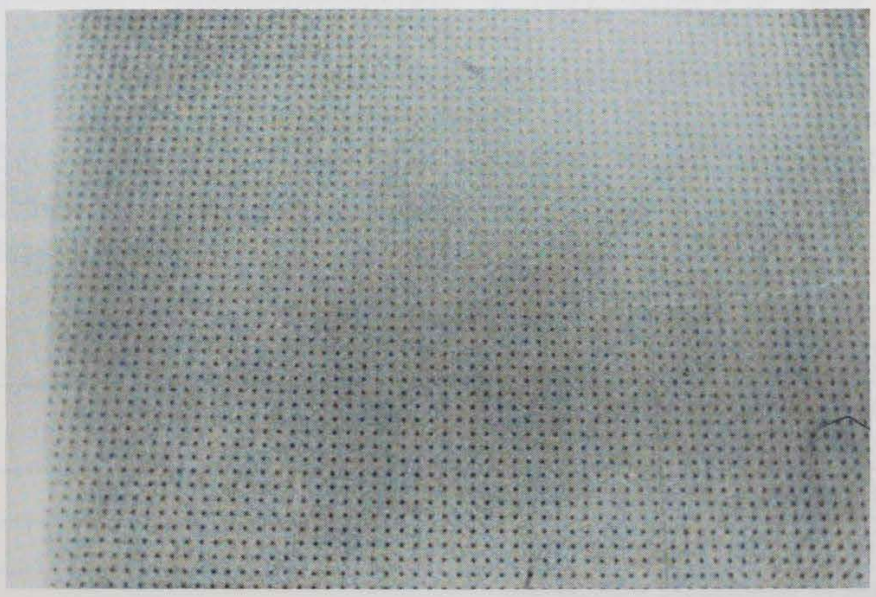

Illustration 34

\section{Illustrations 29-34}

Unstable Pattern III is characterized by distinct shifts and observable changes in filmmaking behavior. 
BB: $\quad$ You know what was funny about it? In the beginning we just all filmin' all of our-everything, and then ... at the end of it it's all us, and all people. That was funny; in the beginning was all about buildings and stuff, and at the end it was all people in it. Why did we do that?... I think we were bashful at the beginning. . .

SK: $\quad$ That's what I think we should do with the movie, film people, because when you just film scenery I don't like it. Do you?
Referring to Figures 3 and 10, these girls changed their behavior to conform more to a Stable Pattern I set of characteristics, specifically in item 1 (they continued consistently to film people), item 4 (they now almost exclusively filmed themselves), and item 8 (they ignored unknown people). The girls also made several shots of Chalfen (see item 7), in conformance with behavior observed for all the film groups. These changes are illustrated in Figure 10.

\section{Figure 9}

\section{Cell 6 Event-Component: On-Camera Filming-}

Participants

\section{Characteristics}

\begin{tabular}{lll}
\hline Stable & & Unstable \\
Patterns & Pattern III \\
I & II & 1st time*
\end{tabular}

2nd time ${ }^{\dagger}$

1 Original size of group enlarged during and because of on-camera filming

\begin{tabular}{llll}
\hline $\mathbf{2}$ & Original size of group remained the same & $\mathbf{x}$ & $\mathbf{x}$ \\
\hline $\mathbf{3}$ & Tendency to consistently put people in the film & $\mathbf{x}$ & $\mathbf{x}$ \\
\hline $\mathbf{4}$ & Use of the filmmakers themselves & $\mathbf{x}$ \\
\hline $\mathbf{5}$ & Use of peer group friends & & \\
\hline $\mathbf{6}$ & Use of parents/or adult relatives & $\mathbf{x}$ & $\mathbf{x}$ \\
\hline $\mathbf{7}$ & Use of Chalfen-project director & $\mathbf{x}$ & $\mathbf{x}$ \\
\hline $\mathbf{8}$ & Use of outsiders, people personally unknown to filmmakers & $\mathbf{x}$ \\
\hline
\end{tabular}

*Refers to first 200 feet of practice filming

${ }^{\ddagger}$ Refers to second 200 feet of practice filming

\section{Figure 10}

\section{Cell 6 Event-Component: On-Camera Filming- Participants}

\begin{tabular}{|c|c|c|c|c|c|c|}
\hline & Characteristics & $\begin{array}{l}\text { Stable } \\
\text { Patterns } \\
\text { I }\end{array}$ & II & $\begin{array}{l}\text { Unstable } \\
\text { Pattern III } \\
1 \text { st } \\
100^{\prime * * *}\end{array}$ & $\begin{array}{l}\text { 2nd } \\
100^{\prime+}\end{array}$ & later \\
\hline 1 & $\begin{array}{l}\text { Original size of group enlarged during and because of on- } \\
\text { camera filming }\end{array}$ & $x$ & & & & $x$ \\
\hline 2 & Original size of group remained the size & & $\mathbf{x}$ & $\mathbf{x}$ & & \\
\hline 3 & Tendency to consistently put people in the film & $\mathbf{x}$ & & $\mathbf{x}$ & $\mathbf{x}$ & $\mathbf{x}$ \\
\hline 4 & Use of filmmakers themselves & $x$ & & & $\mathbf{x}$ & \\
\hline 5 & Use of peer group friends & $\mathbf{x}$ & & & & $\mathbf{x}$ \\
\hline 6 & Use of parents and/or adult relatives & & & & & $\mathbf{x}$ \\
\hline 7 & Use of Chalfen-project director & $\mathbf{x}$ & $\mathbf{x}$ & $\mathbf{x}$ & $\mathbf{x}$ & $\mathbf{x}$ \\
\hline 8 & Use of outsiders, people personally unknown to filmmakers & & $x$ & $x$ & & $x$ \\
\hline
\end{tabular}

*Refers to first 100 feet of first practice filming

+Refers to second 100 feet of first practice filming

tRefers to second session of 200 feet of practice filming 


\section{Illustrations 35-44}

Another Unstable Pattern III group (white lower-class females) appeared to shift toward behavior characteristic of Stable Pattern I.

35-39 Group 7 filmmakers chose to make their first practice film in a large open park known as Cobbs Creek. While surrounded by trees, grass, and open space, they sought out instances of human activity. Instead of filming objects of nature they focused their cameras on unknown people-a mounted policeman, several boys playing in a creek area, three people smoking while sitting next to a tree, a man on the sidewalk, and the driver and occupants of a bus.

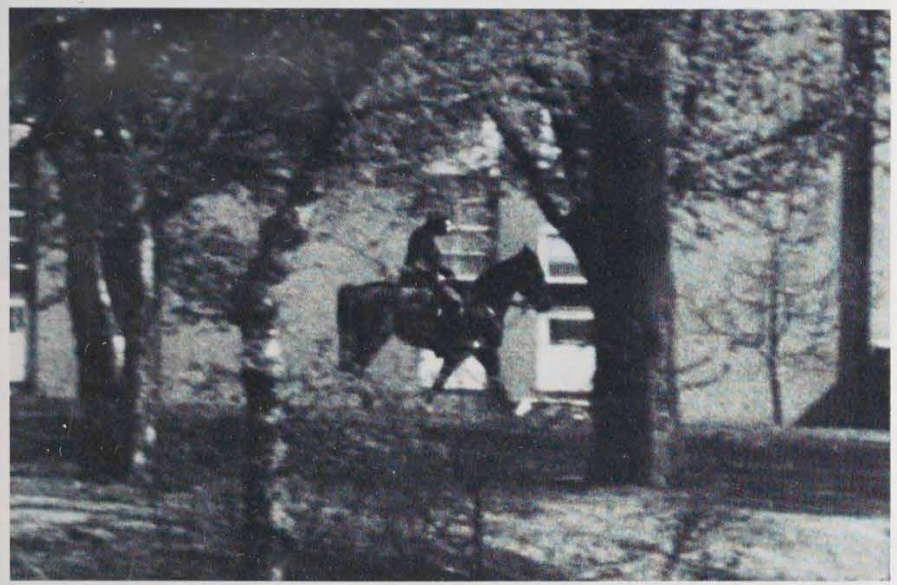

\section{Illustration 35}

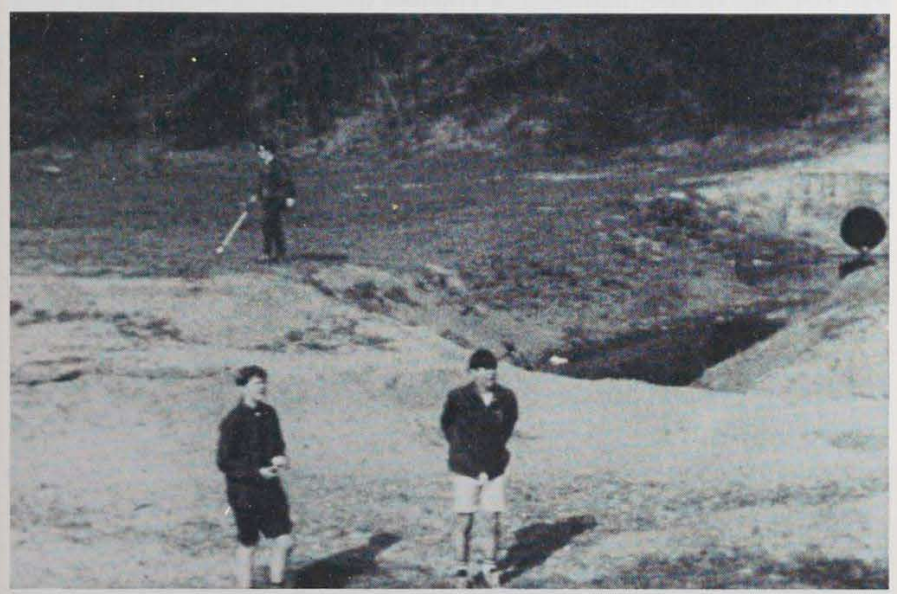

\section{Illustration 36}

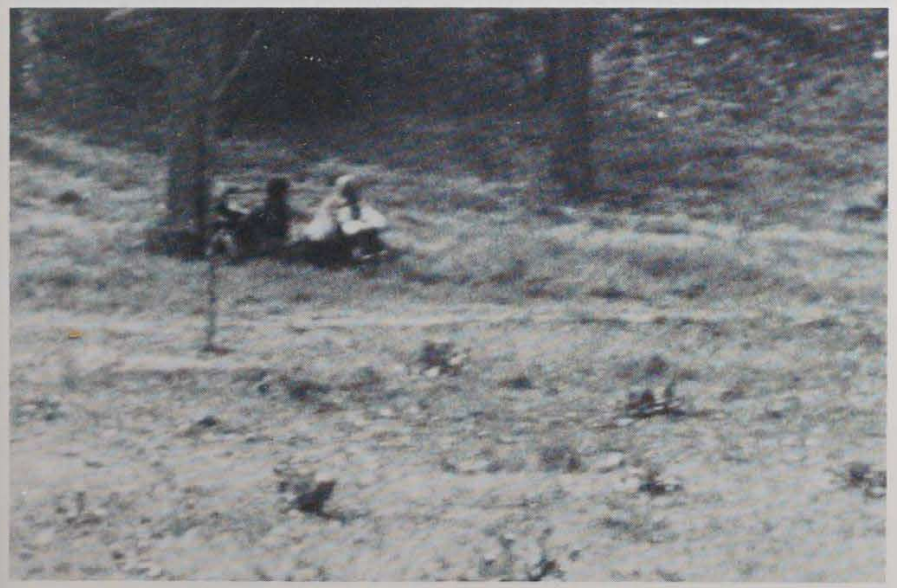

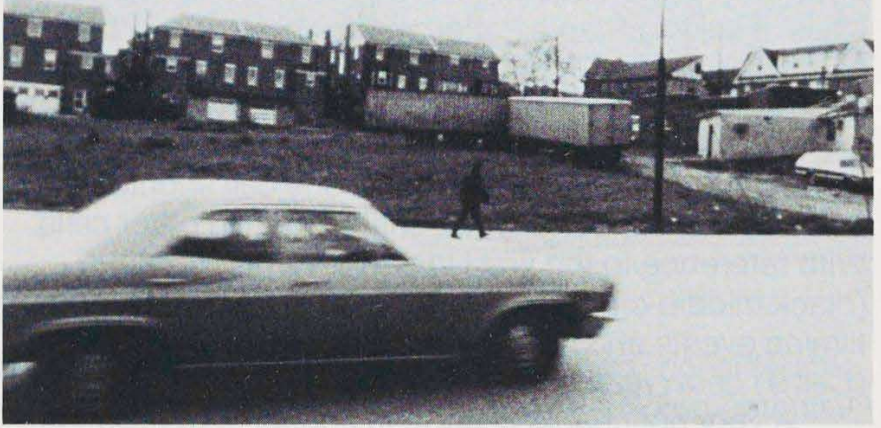

\section{Illustration 38}

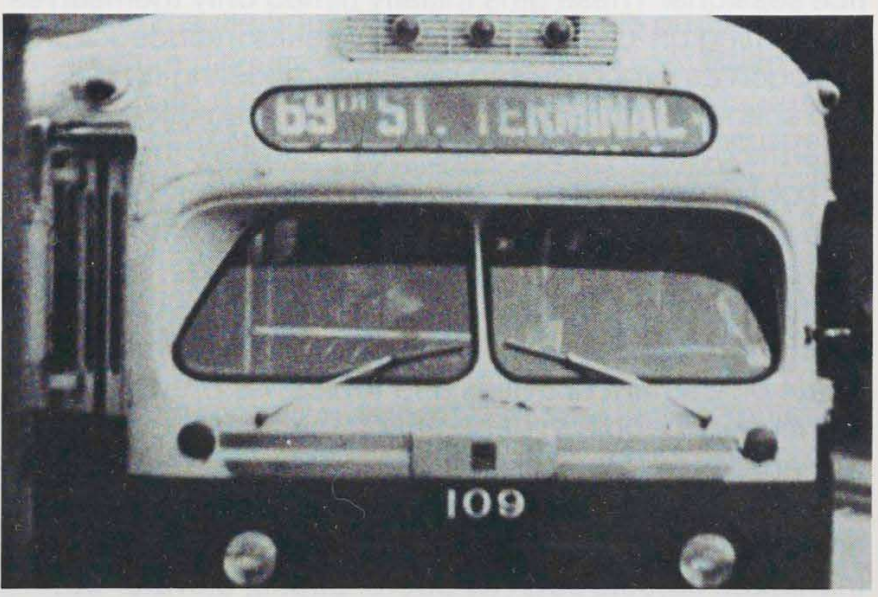

Illustration 39 
40 Group 7 filmmakers were initially unwilling to appear in their movies. Several times they were observed ducking away from the camera. Unknown people were selected as on-camera participants.

Later practice filming conformed to behavior described for their second roll of outside shooting. The majority of their footage again showed people, and the filmmakers themselves were most frequently seen. However, they also filmed anyone and everyone (including Chalfen) who came into the area where they were shooting. In this latter behavior, these girls shared the SP II tendency to film unknown "outsiders" (see item 8, Figure 10).

Even within sessions devoted to practice filming, a change in preference for on-camera participation has been observed. Though the sociovidistic behavior of this lower-socioeconomic white group drew on characteristics of the two Stable Patterns, the observed shift located this group's preferences much closer to the pattern established for the lower-class way of making a movie.

It is expected that sociovidistic behavior is coordinated across cells; shifts found in one cell should be related to, and expected from, shifts found in other cells. With reference to the first Unstable Pattern III group (black middle-class girls) relevant relationships between filming events and topics (Cell 8 ) and message form (Cell 9) deserve attention.

A very noticeable change in choice of appropriate film topics occurred between the first and second practice sessions. These girls initially filmed only themselves performing on-camera skits. These skits included activities such as synchronized dancing, modeling clothes, and scenes of gun-dueling and a melodramatic farewell. In terms of findings for Cell 8 (see Figure 5), their behavior conformed to Stable Pattern I for items 1 and 3 and also included the dancing activity listed in item 7.

However, after the girls viewed this footage, and during the second practice filming, they radically altered their on-camera presence and their choice of appropriate on-camera activities and topics. As previously mentioned, people in general and the filmmakers in particular appear much less frequently. There was some attempt to catch people in natural behaviors, unaware of an operating camera. Much more attention was paid to inanimate objects such as doors, books, elevator buttons and numbers, toilets, Kotex dispensers, sculpture, a water fountain, coffee and cookie machines, and patterns of dots on a wall. Again, with specific reference to items 2, 4, and 9 in Figure 5, the shift has been in the direction of SP II as illustrated in Figure 11.

The last example of shifting behavior to be described for the black middle-class film group involves the relationship of filming and message form. Findings presented in Figures 6 and 8, for Cells 9 and 12 respectively, indicate that Stable Pattern I groups tended to present themselves and their actions as the message form. The focus of attention was the behavior of someone (usually a member of the film group) while oncamera. It should be clear that these characteristics accurately describe the behavior of this Unstable Pattern III group, as illustrated in Figure 12.

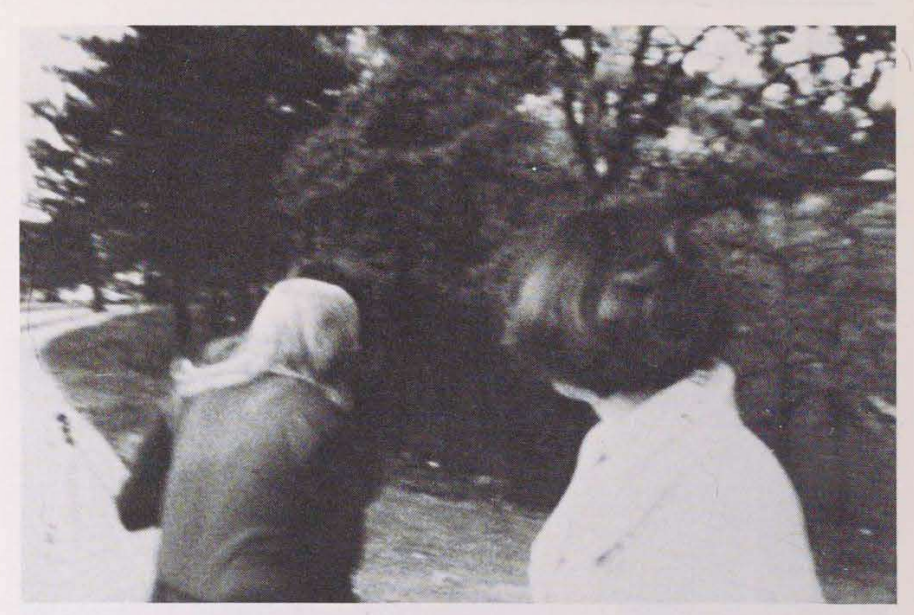

Illustration 40

However, while we notice that findings in Cell 9 are more relevant to Pattern I, characteristics of Cell 12, the relationship of behind-camera events and message form, are more relevant to Pattern II. As outlined in Figure 13, the filmmakers in the black middle-class group changed their filming attentions to manipulating the camera and testing its potential in purposefully altering the message form. Emphasis shifted away from a total preoccupation with what happened in front of the camera and using the camera primarily as a recording device. These girls began to explore using the camera to manipulate and possibly distort imagery as well as collect it (see items 4 and 8 of Figures 8 and 13).

In the second 200 feet of practice, several behindcamera skits were attempted that resembled behindcamera performance of the white middle-class boys' group. Thus for several additional items, the changes noticed in the analysis of Cells 9 and 12 again indicate a shift for the black middle-class girls toward Stable Pattern II sociovidistic behavior.

The patterned changes of the black middle-class group has clearly put them closer to a white middleclass way of making a movie than to the pattern established by the black lower-class groups. It is very tempting to speculate on parallel findings on social mobility and changes in sociovidistic behavior. While this topic deserves additional attention, it is not the central theme of this report. 
41-44 The girls in Group 7 dramatically changed their choices during the second practice shooting. Choosing to film in a cemetery, they decided to film themselves while smoking, and while dancing in shortskits, and they enjoyed mugging for the camera. These changes produced a version of Stable Pattern I filmmaking, characteristic of lower-socioeconomic-class teenagers.

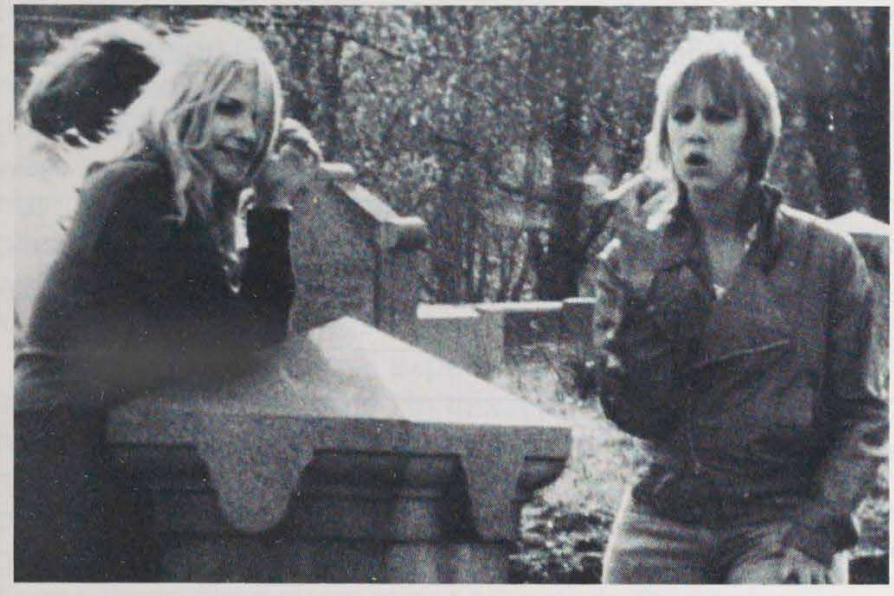

Illustration 41

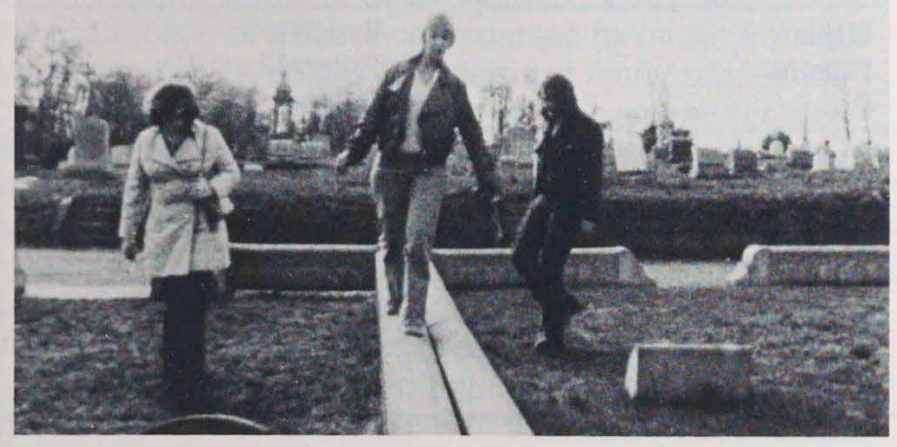

Illustration 42

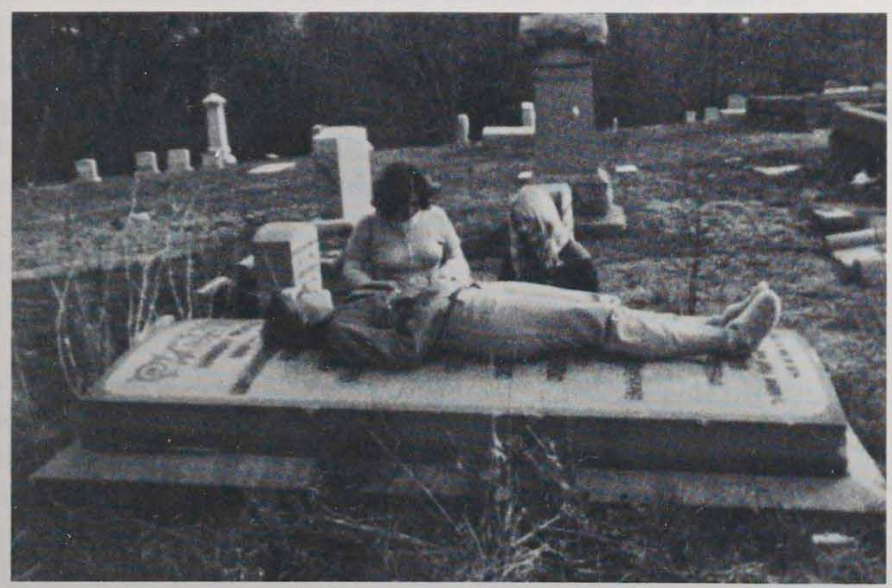

Illustration $\mathbf{4 3}$

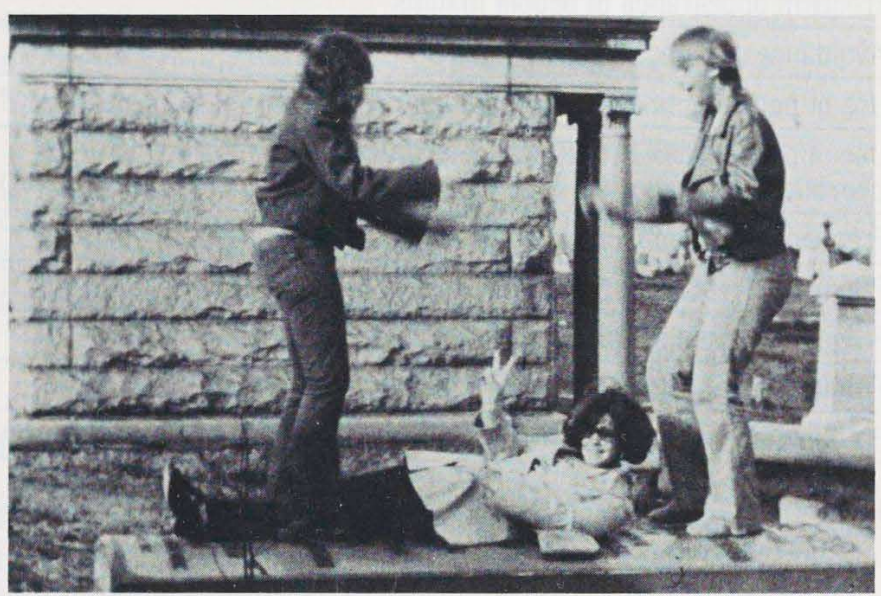

Illustration 44

\section{Hints of Collaborative Evidence}

Since completing the Philadelphia Project, considerable time has been given to locating and examining potential sources of comparable data. A search has been made for examples of teenage filmmaking that might confirm or negate results from Philadelphia. I have profited greatly from discussions with Rodger Larson, Brian Sutton-Smith, Tony Hodgkinson, Rick Weise, Maureen Gaffney, Sven Norlin, DeeDee Halleck, Kit Laybourne, and Bob Aristarco-all of whom are professionally concerned with children's filmmaking. In almost all cases teenage films have been produced ùnder different circumstances; different teaching methods, motivations, and expectations have guided other projects. ${ }^{8}$ While almost everyone could offer some form of anecdotal contribution in general agreement, few specific examples could be produced and directly related to the sociovidistic findings reported in this paper.

The most interesting example of similar results may be found in a film entitled Young Filmmakers (1968). ${ }^{9}$ This film documents the "World's First Conference of Young Filmmakers" organized by John Culkin. Approximately one quarter through the film a narrator asks the following questions: "If a man is suddenly given a new voice, what would he say? With new eyes, what would he look at?' 'We wanted an answer in our context (of children's filmmaking). The narrator continues: "So we chose two groups of very dissimilar boys and gave each the chance to make an instant movie in the same limited environment." The first group of four upper-middle-class white teenagers came from a private school in suburban Philadelphia. These boys had learned basic filmmaking in their school's media course and had made two films before this experience. The other group consisted of five black and Puerto Rican teenagers from the Lower East Side of New York. Four members were high school dropouts. They had learned filmmaking at the University Set- 


\section{Figure 11}

Cell 8 Event-Component: Filming-Topics

\begin{tabular}{|c|c|c|c|c|c|}
\hline & Characteristics & $\begin{array}{l}\text { Stable } \\
\text { Patterns } \\
\text { I }\end{array}$ & II & $\begin{array}{l}\text { Unstable } \\
\text { Pattern III } \\
\text { 1st time }{ }^{+}\end{array}$ & 2nd time $e^{\ddagger}$ \\
\hline 1 & Frequent appearance of people in films & $\mathbf{x}$ & & $\mathbf{x}$ & \\
\hline 2 & Avoidance of using people in films & & $\mathbf{x}(M) *$ & & $\mathbf{x}$ \\
\hline 3 & Use of people acting and aware of an operating camera & $\mathbf{x}$ & & $\mathbf{x}$ & \\
\hline 4 & $\begin{array}{l}\text { Use of people seen in "natural" behaviors unaware of } \\
\text { operating camera }\end{array}$ & & $x$ & & $x$ \\
\hline 5 & Frequent attention to sports activity & $\mathbf{x}$ & & & \\
\hline 6 & Frequent attention to fighting activity & $\mathbf{x}$ & & & \\
\hline 7 & Frequent scenes of dancing, drinking and/or smoking & $\mathbf{x}$ & & $\mathbf{x}$ & \\
\hline 8 & Frequent use of scenes of nature and animals & & $\mathbf{x}$ & & \\
\hline 9 & Frequent appearance of inanimate objects & & $\mathbf{x}$ & & $\mathbf{x}$ \\
\hline
\end{tabular}

*(M) indicates male tendency

${ }^{+}$Refers to first 200 feet of practice filming

${ }^{\ddagger}$ Refers to second 200 feet of practice filming

\section{Figure 12}

\section{Cell 9 Event-Component: On-Camera Filming - Message Form}

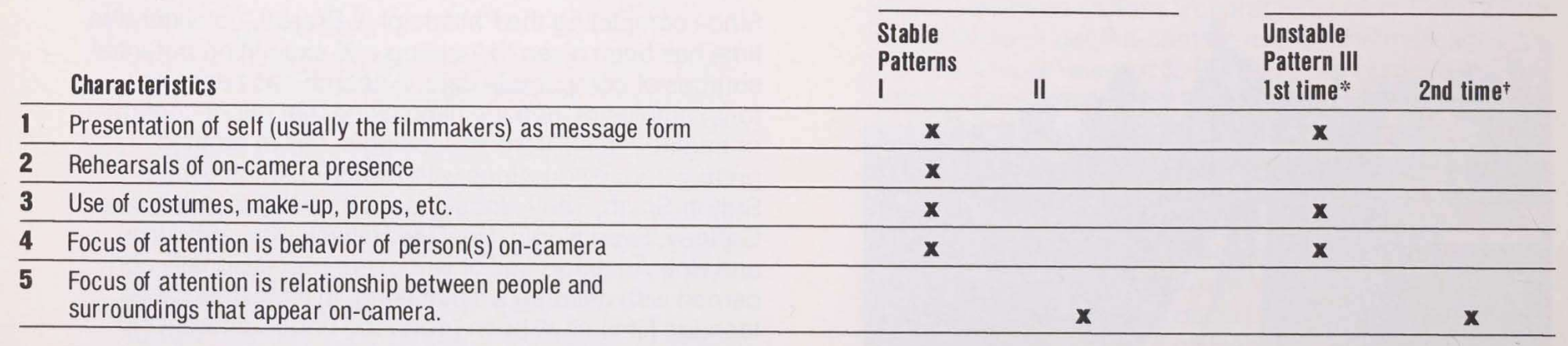

Figure 13

Cell 12 Event-Component: Behind-Camera FilmingMessage Form

\begin{tabular}{|c|c|c|c|c|c|}
\hline & & & \\
\hline & Characteristics & $\begin{array}{l}\text { Stable } \\
\text { Patterns } \\
\text { I }\end{array}$ & II & $\begin{array}{l}\text { Unstable } \\
\text { Pattern III } \\
\text { 1st time } \\
\end{array}$ & 2nd time ${ }^{+}$ \\
\hline 1 & $\begin{array}{l}\text { Tendency to shoot film in the sequence prescribed by script or } \\
\text { outline }\end{array}$ & $\mathbf{x}$ & & & \\
\hline 2 & Tendency to shoot film "out of sequence" & & $\mathbf{x}$ & & \\
\hline 3 & Simple use of camera technology & $\mathbf{x}$ & & $x$ & \\
\hline 4 & Elaborated use of camera's abilities & & $\mathbf{x}$ & & $\mathbf{x}$ \\
\hline$\underline{5}$ & Preference for long camera takes of fabricated scenes & $\mathbf{x}$ & & $\mathbf{x}$ & \\
\hline 6 & Preference for short camera takes of "natural" scenes & & $\mathbf{x}$ & & $\mathbf{x}$ \\
\hline 7 & Camera used to produce a record or copy of reality & $x$ & & $\mathbf{x}$ & \\
\hline 8 & Camera used to collect, distort and manipulate imagery & & & & $\mathbf{x}$ \\
\hline
\end{tabular}


tlement Club, a federally funded project directed by Rodger Larson (Roddick 1967; O'Connor 1967) and had cooperated on the production of several films. Both groups were given $16 \mathrm{~mm}$ cameras and film stock and were asked to make a film using the same spaces in a hotel. The young filmmakers were given half an hour to plan their film and one hour to shoot it. Each group worked independently, and presumably neither group knew what the other was doing.

Results of this informal experiment strongly resemble several findings presented in this report. The New York teenagers made a gangland-type film which featured the misadventures of two "businessmen" trying to see "the boss" about a $\$ 1$ million "investment." Following an organized story line set to the theme music from Goldfinger, these filmmakers chose to include themselves in every scene. Their characterizations of unusual types required actors to dress up and to "act up" for on-camera performances.

In contrast, the private school teenagers from Philadelphia produced more of an abstract movie "about" the production of a film. Accompanied by music from a Moog synthesizer, this film consists of many sequences of isolated objects (e.g., a script, desk, camera, reels of films, synchronizer, tape recorder, pieces of sculpture, water fountain, newspaper headline) shot in short takes and edited into a quickly paced montage. The filmmakers or any form of human activity are almost never seen. The film ends by having a film box-presumably the completed film-placed in an elevator.

The material presented in Young Filmmakers demonstrates considerable overlap with the sociovidistic results discussed in this report. Two groups of teenagers from different sociocultural backgrounds produced distinctively different kinds of films. ${ }^{10}$ We are given independently produced examples and evidence for the existence of several key characteristics of Stable Patterns I and II as they emerged from the sociodocumentary research projects in Philadelphia. Preferences for oncamera vs. behind-camera performance were maintained; contrasting patterns of topics, message form, and code appear once again.

For instance, both groups independently decided to include an elevator scene in each film. When the elevator doors open in the New Yorkers' film, we see two members of the group dressed as gangster "toughs." The other filmmaking group chose to shoot the same elevator by using a point-of-view camera technique. This scene includes interior details of the elevator and adjacent office; however no people are in these shots. In this comparative examiple, characteristics of Stable Pattern I are illustrated by the lower-socioeconomic-class teenagers' preferences for on-camera performance and for using themselves as centers of attention. In contrast, Stable Pattern II preferences for behind-camera activity, reluctance to be "in" the movie, and a look-at-me-see meta-message are evident in the middle-class film production. In addition, other choices involving story line, use of inanimate objects, editing techniques, and synchronized sound further differentiate the two Stable Patterns.

In summary, many questions remain regarding the generalizability of these findings. It is very difficult to find comparable examples of nondirective projects-projects that allow a freedom of indigenous expression with respect to both content and form.

\section{Conclusions}

Primary objectives of the Philadelphia Project were to apply sociodocumentary methods to generate comparative examples of teenage film communication and to observe the influence of social and cultural factors in several examples of film production. The purpose of this report has been to demonstrate the systematic application of a sociovidistic scheme of description and analysis to the products and processes of teenage film communication.

The research demonstrated that film communication can be studied through a series of event-component relationships; the proposed sociovidistic scheme has provided us with a productive tool for discovering patterns of similar and different behaviors across several filmmaking projects.

In turn, research findings have produced a better understanding of the variable nature of a film communication process. The process looks quite different when different culturally defined groups organize film communication for the first time. It is not surprising to find that all teenage subjects could learn to use $16 \mathrm{~mm}$ professional filmmaking equipment with considerable ease and confidence. It is perhaps more relevant to understand that while all groups of young people were intellectually and physically capable of making movies, not all groups wanted to participate in moviemaking in the same way, and some groups did not want to participate at all.

Perhaps the most substantial and provocative finding of the Philadelphia Project has been the emergence of two distinctly different patterns of sociovidistic behavior. Young people from two unlike subcultures have produced two unlike but stable patterns of film communication. Specifically, filmmaking subjects from black and lower-socioeconomic backgrounds preferred to use and manipulate themselves and familiar aspects of their immediate environment in their symbolic communication. In contrast, the white and more affluent subjects preferred to use and manipulate (more than record) images of unfamiliar things and people, other than themselves, found in areas away from their familiar environment. This finding has several interesting relationships to work done on the importance of class and ethnic variables. 
The ethno-class differences, suggested by the separation of Pattern I and Pattern II behaviors, have many implications for future inquiry. For instance, there may exist a direct relationship between a preference for manipulating symbolic events and a feeling for control over one's environment. It is also suggested that a desire and ability to actually explore and manipulate an environment of natural events may be correlated with a preference to explore and manipulate symbolic events.

The findings for Unstable Pattern III further emphasize the importance of the "social class" variable. When films were made by anomalous groups (from black middleclass and white lower-class backgrounds), the sociovidistic shifts seemed to be controlled by the class variable. The black middle-class group of girls tended to act more like the white middle-class groups of Stable Pattern $\mathrm{II}$, and the white lower-class groups shifted their behavior to conform more to the black lower-class Pattern I.

Further implications of this study are related to the development and demonstrated application of the sociovidistic scheme of analysis. Investigators now have a theoretical and analytical foundation for future work. ${ }^{11}$ However, the appropriateness or usefulness of this scheme of events and components for other film genres and other codes and modes of pictorial communication remains problematic for the moment.

\section{Notes}

1 These comments are not offered as negative criticism of many interesting projects and articles on children's filmmaking. It is acknowledged that projects, articles, and reports are produced for many reasons satisfying different needs, questions and audiences. This report does not include filmmaking projects done outside the United States.

2 This is not to say that Worth and Adair paid no attention to context or had no plan for describing context. They list six "areas of context": (1) the learning situation, (2) the choice of Navajo students, (3) the students' choice of actors for their films, (4) their choice of film subjects or themes, (5) their method of working (technical and perceptual), and (6) the interrelation of their filmmaking and their community (1972:139140). The point here is that the sociovidistic scheme incorporates and realigns these six areas within a framework more directly related to another communicative modality, namely, speech.

3 Further explanation of these points will appear in a forthcoming paper by the author entitled: "From Verbal to Visual: Sociolinguistics, Vidistics and Sociovidistics." In future discussions it may prove useful to distinguish Worth's predominant interests as "psychovidistic" from work described in this report as sociovidistic. With specific reference to children's filmmaking, see Sutton-Smith $(1977,1979)$ for examples' of the former, and Chalfen (1974) and Chalfen and Haley (1971) for the latter.

$4 \mathrm{I} \mathrm{am}$, in part, making certain paraphrases from the work of Dell Hymes (1974:83) and Bauman and Sherzer (1974:6), substituting visual terms for linguistic/verbal references.

5 The project was supported by a three-year research grant from the $\mathrm{Na}$ tional Institute of Mental Health (No. S-R01-MH17521) entitled "Exploring Social Perception with Film. " The grant was administered by the Philadelphia Child Guidance Clinic where I worked as a Research Associate between 1967 and 1972 .
6 I am fully aware that the terms "social class," "middle class," and "lower class" have had precise meanings for different social scientists. When the adjectives "lower" or "middle" accompany the use of "social class," they are meant in a relative frame of reference. Thus some groups were "higher" or "lower" relative to other groups in the study. NO invidious comparisons are implied.

7 Jay Haley was Director of Research at the Philadelphia Child Guidance Clinic. He served as chief consultant on the NIMH research grant.

8 The Minnewaska Symposium on Child-Made Films provided an excellent opportunity to examine results of many alternative filmmaking programs for young people (Chalfen 1977; Covert and McBride 1977; Shapiro 1977).

9 This 25-minute black-and-white film was produced by David Hoffman as part of his work for Public Broadcast Laboratory. The conference, which attracted 740 young filmmakers and 500 teachers, was held in New York's Park Sheraton Hotel. Young Filmmakers may be rented from Brandon Films.

$\mathbf{1 0}$ In the last section of Young Filmmakers, the two groups of teenagers discussed their films after seeing both productions. They questioned why they didn't make the same kind of film. One black teenager from the Lower East Side presented a cogent explanation: "I have not had the same experiences [as the white upper-middle class teenagers]

They take stuff and make it into life. To me, this is like a dream; I don't know what it is to them. If I had the time to sit back and look around and put things together, I could make a wonderful thing. I know they have time for this-I don't have time-I don't have so much feel for that. I make a film of the first thing that comes to my head, and what I know-how people carry on. And that's what I think will catch the audience's attention."

In contrast, a spokesman for the upper-middle-class Philadelphia group explained: "We were making the film today as an experiment We were not trying to prove any points, not that there's no point in terms of moral or underlying social meaning. The point is that the visual imagery was supposed to create some idea."

11 To my knowledge, three studies have used the sociovidistic scheme, namely Musello's work on snapshot communication (1980), Intintoli's (1979) proposal for studying the production of television documentaries, and Aristarco's fieldwork on children's filmmaking (1980). At the time of this writing results of the Aristarco project are not complete.

\section{Appendix: Summary of Sociodocumentary Films}

\section{Stable Pattern I: Black Lower-Class Groups}

Group 1. The first group of boys produced a 13-minute film titled What We Do on Saturdays on Our Spare Time. In their outside practice footage, shot in a local parking lot, the boys filmed themselves playing football, fighting, acting drunk, and getting fresh with two girls. A lot of posing for the camera characterizes these shots. Practicing inside a settlement house, they filmed themselves playing Ping-Pong, dancing, and being interviewed.

Their sociodocumentary film is about what they like to do as a group on a typical Saturday. We see them playing Ping-Pong and enjoying themselves in the recreation basement of the settlement house. The film shows the group walking upstairs and out the front door. While walking to a parking lot two blocks away, they window-shop, check a telephone box for forgotten change, and buy french fries. The major portion of their film is devoted to scenes of playing football. In the middle of the game, an argument develops into a mass fight scene. 
The boys make amends and continue to play football. Later, they leave the parking lot, to reappear, staggering in a drunken manner. Fighting again erupts, followed by another truce. In the end, the boys leave the parking lot, presumably on their way home. The film's sound track consists of an interview by the boys (on why they like having a film club) and a jazz piece titled "Moejoe."

Group 2. The second group to make a film was a girls' club called the "Soul Sisters." They produced a 71/2-minute film titled Don't Make a Good Girl Go Bad. In their practice footage, the girls concentrated on filming themselves in scenes of dancing and fighting; other forms of competitive behavior include flexing their arm muscles and cigarette smoking. The girls were not interested in using the camera or in editing activities.

The story line of their finished film involves a conflict between an adolescent unwed mother and her mother. After an argument and several mutual insults, the daughter slaps her mother and is thrown out of their home. The unwed daughter and her infant child then visit a girlfriend's apartment and are invited to stay as long as needed. The girls in the apartment celebrate the arrival of their new roommates with a party. An adequate supply of liquor, cigarettes, and drugs are enjoyed as the girls appear in scenes of dancing, drinking, smoking, swearing, etc. Eventually the party evolves into a drunken brawl. When one of the girls tries to get additional drugs, she is discovered by the police. The police raid the party and jail all the girls except the unwed mother and her baby. The elder mother then enters the apartment and takes away her grandchild. The daughter gets up from lying drunk on the couch and follows her mother out the door to end the film. (For a more complete account of this project, see Chalfen and Haley 1971.)

Group 3. A group of black teenage boys called the "Nobleteens" comprised the third filmmaking group. In their outside practice shooting, these boys emphasized the filming of themselves playing basketball, standing in front of a graffiti-laden wall, and in scenes of hamming for the camera. For their inside practice, they again shot scenes of themselves fighting and of the mugging and robbing of an adult drunk.

Although the boys had ideas of making a film of their street life, no major film was produced.

\section{Stable Pattern II: White Middle-Class Groups}

Group 4. In the first project with middle-class teenagers, a group of boys produced a 7-minute film titled WPFG-M1. Practicing outside, these boys concentrated on filming buildings, brick walls, cement surfaces, bushes, trees, pipes, lamp posts, etc. They infrequently filmed themselves, using slow motion and pixilated motion techniques. Their inside practice footage shows clocks, desks, chairs, corridors, coat hangers, and IBM machines.

WPFG-M1 is a quickly paced film which starts with a scene of a sun rising accompanied by the theme music from Kubrick's 2001. A series of intercut short shots of a dog, of lettering that reads "I AM ME," etc., lead into many scenes of animal life (such as ducks, birds, swans, butterflies, a rabbit, etc.), filmed in heavily foliated surroundings of streams, ponds, and the like. The boys are seen in very short scenes of batting a peanut with an extended tripod and dancing in pixilated motion. Some shots are as short as two and three frames and occasionally are edited upside-down. The film ends as one of the boys gives an obscene finger gesture to the camera.

Group 5. The fifth group in the project was a group of girls, who made a 14-minute film titled God. These girls devoted equal parts of their outside practice to filming other people (only occasionally themselves), fountains, buildings, and foliage. For their inside practice, they filmed short skits which involved sexy dancing on a table, an elevator, and a glass flower. Some of the shots were made with the camera on its side, and, in one case, in slow motion.
God begins with 45 seconds of black leader while "Every Night" is heard on the sound track. One of the girls reads from Gibran's The Prophet over many scenes of sunrays and branches, reflections in rivers, and dogs running in a park. Other music is then heard over scenes of unknown people pushing a baby carriage, playing football, etc.; many scenes of animals such as dogs, horses, ducks, and swans are intercut with shots of human activity. The girls appear briefly in the film as they skip around a water fountain. The film ends with a sequence of statues of human figures and the word "God..." which is followed by 3 minutes of black leader over James Taylor singing "Country Road."

\section{Unstable Pattern III}

Group 6. A group of white lower-class boys from southwest Philadelphia comprised the next group. Outside practice filming was done in a neighborhood park. They concentrated on forms of human and animal life by filming people walking through the park ("faces reacting to the camera"), young children playing on a park bench, dogs running, playing and mating, etc. They filmed themselves several times and regretted they had not brought a football with them.

Although no final film was produced, they suggested subjects such as parts of their everyday lives, especially when they were doing something bad or illegal; staging a football game in a trolley car; and making a "geographical film" at a university biology pond.

\section{Group 7. The next film project was completed by a group of white} lower-class girls who made a 39-minute film titled The Life of Man. Outside practice footage was shot at Cobbs Creek and a local cemetery. They mainly shot people (kids playing, a park guard on horseback, people in passing buses and cars), and they filmed themselves in short skits. They duplicated this behavior when they practiced filming indoors.

The Life of Man begins with the Biblical past as Adam accepts and bites into an apple from Eve. A 4-year-old boy and girl are heard to say "sugar and spice and everything nice, that's what little girls are made of" and "snakes and snails and puppy dogs' tails, that's what little boys are made of." The following shots show us infants in hospital beds and in cribs at home; young children are shown as happy and sad. Other young children are shown sitting on sidewalks and smoking followed by a shot of a youngster studying. Scenes that follow include adolescents dancing, jumping rope, and taking drugs. As the film progresses we are shown examples of good and bad parents, people loafing and others at work, and then bums on Skid Row. The film ends with an old lady dying in her rocking chair followed by a cemetery scene with a man (Chalfen) kneeling and praying in front of a gravestone. Each section of the film, which usually consists of only one scene, is accompanied by a different piece of music; the film ends in silence when the cemetery scene appears.

Group 8. The last filmmaking project involved a group of black middleclass girls. This group concentrated on shooting short dramatic and humorous skits for their outside practice. More often than not, they chose to film themselves in dancing and modeling poses. There were several attempts at trick photography in terms of having people appear and disappear from one frame of the film to the next. For their inside practice, they chose to film other people as well as themselves in a library, a bathroom, and on an elevator. Again the emphasis was on performing humorous extemporaneous skits. The camera was again used to make people appear and disappear quickly, and there were several slow- and fast-motion shots.

Before these girls decided not to produce a film as a group, they struggled with agreeing on such suggested topics as a film about children, something about their school life, or the problems of a polluted environment. 


\section{References}

- Achtenberg, Ben

1967 Making "Not Much to Do": An Experiment in the Use of Documentary Filmmaking as a Tool in Communication Research. Master's thesis, University of Pennsylvania.

- Anderson, Yvonne

1969 The Yellow Ball Workshop. Media and Methods 5:48-49.

- Aristarco, Bob

1980 Adolescent Film Production: A Case Study Involving Participant Observation and Multidimensional Scaling. Master's thesis, Temple University.

- Arnheim, Rudolf

1969 Visual Thinking. Berkeley: University of California Press.

- Bauman, Richard, and Joel Sherzer

1974 Explorations in the Ethnography of Speaking. New York: Oxford University Press.

- Bigby, John

1968 Fade to Black: Seeing Harlem through $8 \mathrm{~mm}$ Eyes. Take One 1(12):20-21

- Brasso, Russ

1974 Making Student Filmmaking Work. Media and Methods 10 (January): 27

- Carrico, Paul

1969 Student Filmmaking, Why and How. Media and Methods 6 (November): 41-45.

- Chalfen, Richard

1977 Perspectives on Children's Filmmaking: The Minnewaska Symposium. Film Library Quarterly 10(1-2):60-65.

1974 Film as Visual Communication: A Sociovidistic Study in Filmmaking. Ph.D. diss., University of Pennsylvania.

- and Jay Haley

1971 Reaction to Socio-Documentary Filmmaking in a Mental Health Clinic. American Journal of Orthopsychiatry 41(1):91-100

-

1972 How Groups in Our Society Act When Taught to Use Movie Cameras. In Through Navajo Eyes: An Exploration in Film Communication and Anthropology. Sol Worth and John Adair. Pp. 228-251. Bloomington: Indiana University Press.

- Covert, Nadine, and Fern McBride

1977 The Minnewaska Report: Symposium on Child-Made Films. - Culkin, John Sightlines (supplement) 11(1):2-5

1966 I was a Teenage Movie Teacher. Saturday Review 49 (July):51-53.

- Evans, Gerald B., Robert A. Steer, and Eric W. Fine

1979 Alcohol Value Clarification in Sixth Graders: A Filmmaking Project. Journal of Alcohol and Drug Education 24(2):1-10

- Hilton, Minna

1973 Realistic Expectations in the Media Department of the Harlem Preparatory School. Sightlines 6:9.

- Hodgkinsson, Anthony

1964 Children's Films and Screen Education. Film Comment 2(2).

- Hymes, Dell

1974 Social Anthropology, Sociolinguistics and the Ethnography of Speaking. In Foundations in Sociolinguistics: An Ethnographic Approach. Pp. 83-117. Philadelphia: University of Pennsylvania Press.

1972 Models of the Interaction of Language and Social Life. In Directions in Sociolinguistics-The Ethnography of Communication. John Gumperz and Dell Hymes, eds. New York: Holt, Rinehart.

1964 Introduction: Toward Ethnographies of Communication. In The Ethnography of Communication. John Gumperz and Dell Hymes, eds. Special Publication, American Anthropologist $66(6): 1-34$

- Intintoli, Michael

1979 The Production of Culture: An Ethnography of the Making of a Television Documentary. Ph.D. diss. proposal, Department of Anthropology, Temple University.
- Kohl, Ed

1975 Creative Filmmaking in School. Educational Media International 2:20-24.

- Larson, Rodger, with Ellen Meade

1969 Young Filmmakers. New York: E. P. Dutton.

1966 A Guide for Film Teachers to Filmmaking by Teenagers. New York City Administration of Parks, Cultural Affairs Foundation, Department of Cultural Affairs.

- Lidstone, John, and Don Mclntosh

1970 Children as Filmmakers. New York: Van Nostrand Reinhold Co.

- Mallery, David

1968 Film in the Life of the School. National Association of Independent Schools

- McLuhan, Marshall

1964 Understanding Media: The Extensions of Man. New York: McGraw-Hill.

- Musello, Christopher

1980 Studying the Home Mode: An Exploration of Family Photography and Visual Communication. Studies in Visual Communication 6(1):23-42

- Norlin, Sven

1968 Summary of a Research Study: Suburban Youth and Films Screen Education 42 (January/February)

- O'Connor, John

1967 Teenagers Finding New Action on Film. The Wall Street Journal, June 2.

- Peavy, Charles

1969 Cinema from the Slums. Cineaste 3(2)

- Reinecke, Alma

1974 God Loves the 8mm Mind. English Journal 63:70-73

- Robbin, Dan

1966 Filmmaking as a Youth Program Tool. Richmond, Ca.:

- Roddick, Ellen Neighborhood House, mimeo, files of the author

1967 Movie Bus. Westside News, August 7.

- Shapiro, Edna

1977 The Minnewaska Symposium. Film Library Quarterly 10(34):15-19

- Sutton-Smith, Brian, et al.

1979 A Developmental Psychology of Children's Film Making. Project Report to the Ford Foundation

1977 A Developmental Psychology of Children's Film Making. Paper presented at the Conference on Culture and Communication, Temple University, Philadelphia, files of the author

- Worth, Sol

1972 Toward the Development of a Semiotic of Ethnographic Film. PIEF Newsletter 3(3):8-12

1969 The Development of a Semiotic of Film. Semiotica 1(3):282321.

1966 Film as Non-Art: An Approach to the Study of Film. American Scholar 35:322-334.

1965 Film Communication: A Study of the Reactions to Some Student Films. Screen Education, July/August:3-19.

1964 Filmmaking as an Aid to Action Research. Paper presented at the Society for Applied Anthropology Meetings, San Juan, files of the author

1963 Student Film Workshop. Film Comment 1(5):54-58

- - , and John Adair

1972 Through Navajo Eyes: An Exploration in Film Communication and Anthropology. Bloomington: Indiana University Press.

- Youngblood, Gene

1970 Expanded Cinema. New York: E. P. Dutton. 